\section{Kamu Sektöründe Süreç Yapılandırmasına Teknik Bir Yaklaşım: Kalkınma Ajansları Üzerinde COBIT-5 ile Analiz ve Modelleme}

\author{
Ahmet EFE \\ Ankara Kalkınma Ajansı \\ aefe@ankaraka.org.tr
}

Özet

Kamu sektöründe süreç yaklaşımı yeni kamu yönetimi yaklaşımıyla birlikte gelen toplam kalite yönetimi ve iş süreçleri yönetimi (BPM) yöntemleriyle yansitılmıştır. Türkiye' de 5018 sayılı Kamu Mali Kontrol ve Denetimi Yasası ile performans yönetimi, iç kontrol ve iç denetim bileşenleri birlikte daha sistematik bir nitelik göstermeye başlamıştır. Başbakanlık tarafından 2005 yılından itibaren başlatılan veri ve hizmet envanteri çalışmalarında da süreçler dikkate alınmıştır. Ancak henüz profesyonel anlamda belirli bir standarda göre bir süreç yaklaşımı ortaya konulmamış ve yapılan çalışmalar raflarda bekletilmişlerdir. $\mathrm{Bu}$ nedenlerden dolayı bu çalışmamızda uluslararası bir çerçeve olan COBIT-5 süreçler gerçekleştiricisinin kalkınma ajansları (KA) örneği üzerinden kamu sektöründe uygulanabilir bir yaklaşım olduğu iddiasıyla bu konuda betimleyici, uyarlayıcı ve sorun çözücü bir yaklaşımla analizler yapılmaktadır. Devlet Denetleme Kurulu (DDK) tarafından 2014 yılında belirlenmiş olan KA sorunlarından 2 tanesi üzerinde kök neden analizleri yapılarak süreç modellemesinin olmadığı ortaya konulmaktadır. Yapılan çalışmada KA sorunlarının çözümlenebilmesi için bir süreç modelinin uygulanmasına ihtiyaç olduğu tespit edilerek COBIT-5 süreçler gerçekleştiricisinin boyutları olan paydaşlar, hedefler, yaşam döngüsü ve iyi uygulamalar üzerinden KA için bir analiz ve modelleme yapılabildiği tespit edilmiştir.

Kilit kelimeler: süreç yönetimi, kalkınma ajansları, yönetim süreçleri, COBIT-5
Kamu

Sektöründe

Süreç

Yapılandırma-

sina Teknik

Bir Yaklaşım:

Kalkınma

Ajansları

Üzerinde

COBIT-5 ile

Analiz ve

Modelleme 
Kamu

Sektöründe

Süreç

Yapılandirma-

sina Teknik

Bir Yaklaşım:

Kalkınma

Ajansları

Üzerinde

COBIT-5 ile

Analiz ve

Modelleme

\section{Analysis and Modelling of COBIT-5 Enabler of Processes for the Regional Development Agencies in Turkey}

\begin{abstract}
Process management approach is reflected to the public sector with total quality management (TQM) and business process management (BPM) and redefined with the new public management theory. In Turkey, with the advent of the code of public financial control and auditing 5018 act, performance management, internal control and internal auditing components have shown a more systematic attribute in the legislation. The processes have also been taken into consideration by data and services inventory programme that had been started in 2005 by the Prime Ministry and implemented to all of public bodies. However, as a professional requirement there has not been used any international or national standard and all of the works of inventory, chartings and descriptions left in dossiers idle. It is defined that a implementation of a process model in dynamics of $\mathrm{KA}$ is a requirement for tackling with managerial problems. That's why in this study, process enablers of COBIT- 5 framework is being used in order to conceptually and theoretically understand its applicability to Turkish public sector over the specimen of regional development agencies (KA). As part of this research objective, some root-cause analysis are conducted over the problems of KA defined by State Auditing Board (DDK) in order to find solutions to certain problems and depict a process management model for
\end{abstract} KA.

Key words: process management, development agencies, management processes, COBIT-5

\section{GİRIŞ}

Küresel eğilimler ve $A B$ müktesebatının gerekleri ışığında, Türkiye açısından geleneksel plancılıktan vazgeçilerek yerel sivil, özel, akademi ve kamu sektörünün ortak yönetişimine dayanan bölgesel kaynakların potansiyel ve dinamiklere göre belirlenecek önceliklere tahsisini esas alan yeni plancılık kültürü kalkınma ajansları (KA) ile bölgesel kalkınmacılığa yansıtılmıştır. Türkiye'de 2006 yılında "yönetişim" paradigması üzerine kurgulanan $\mathrm{KA}, \mathrm{AB}$ ilerleme raporlarındaki tespit ve önerilere uygun bir şekilde 5449 sayılı Kuruluş Kanunu ile ortaya çıkmış olmakla birlikte pek çok gelişmiş ülkede yaygın olarak kullanılan bölgesel gelişme ve sosyalekonomik dinamiklerin verimli bir şekilde harekete geçirilmesine olanak tanımayı amaç edinen küçük ölçekli kamu kurumları olup, yönetişim 
mekanizması üzerinde kurgulanmış olmaları ve çoğu noktada özel hukuka tabi olmalarından dolayı klasik Türk amme idaresi geleneğinden ayrışmaktadırlar. 2006 yılından itibaren kurulmaya başlanan ve 2011 yılında düzey-2 (Nutts-II) sinıflandırmasına göre 26 adet olarak farklı bölgelerde kurulmuş olan KA kısa süre içerisinde pek çok projeye finansman sağlamalarına rağmen başarılı olup olmadıkları noktasında bölgesel ölçekte ve ulusal ölçekte sorgulanmışlardır.

KA'nın varlık nedeninin sorgulanması ve KA ile ilgili zayıflıkların ve problemlerin varlığı ile ilgili olarak siyasi, bürokratik, akademik ve iş dünyasından olumsuz söylem ve değerlendirmelerin artması üzerine Cumhurbaşkanlığı Makamınca 2012 yılı sonunda görevlendirilmiş olan Devlet Denetleme Kurulu (DDK) bir yılı aşkın sürede üç vergi müfettişi ve bir Kalkınma Bankası uzmanından oluşturduğu araştırma ve inceleme ihtisas heyeti marifetiyle yaptırdığı kapsamlı çalışmalar, araştırmalar, analizler ve değerlendirmeler sonucunda 2014 yılında çıkarılan ve 830 sayfa olan devasa boyuttaki Araştırma ve İnceleme Raporunda, 43 maddede tespit edilen temel sorunlara parmak basılarak bunların giderilmesi için bazı önerilerde bulunulmuştur (DDK, et al., 2014). Bu öneriler doğrultusunda yapılması öngörülen düzenlemeleri gösteren Kalkınma Bakanlığı (KB) tarafından eylem planı hazırlanmış olmakla birlikte bu çalışmada öncelikle 43 adet sorunu bulunan KA hukuki statüsünün, idare, devlet, bürokrasi ve kamu yönetimi bağlamında analiz edilmesi gerekliliği üzerinde durulmaktadır. Anılan 43 sorunun kökünde yönetişim kurgusunun yanlış yapıldığı varsayımıyla COBIT-5 yönetişim çerçevesinin KA için yeniden kurgulanmayı sağlayacak şekilde uygulanabileceği ve temel sorunlarına çözüm olabileceği hususu doktora düzeyinde çalışmalara da konu edilmiştir. (Efe, 2015)

Bu çalışmamızda KA dinamiklerinde DDK tarafından tespit edilmiş olan 43 adet sorundan 2 tanesi üzerinden kök neden analizleri yapıldığında kurumsal süreç yönetimi ile ilgili problemlerin mevcut olduğu tespit edilmiştir. Süreç yönetiminin yapılandırılması için uluslararası bir çerçeve olan COBIT-5 ile KA dinamiklerinde yapılandırılabilirliği araştırma hipotezi olarak kabul edilerek bu konuda çeşitli analizler yapılmıştır.

Süreç yönetimi, stratejik kurumsal amaçları sağlamayı amaçlayan kurumsal stratejilere göre belirlenmiş olan iş süreçlerini geliştiren ve maksimum performansı sağlayan sistemler, prosedürler, metotlar ve araçlar olarak tanımlanmaktadır (Maříková, Rolínek, Kubecová, \& Vrchota, 2015 , s. 109). Süreç yönetiminin büyük organizasyonlarda olduğu gibi küçük farklılıklarla KOBİ niteliğindeki yapılarda da uygulanması durumunda kurumsal fayda ve avantajların elde edilebileceği pek çok 
Kamu

Sektöründe

Süreç

Yapılandirmasina Teknik

Bir Yaklaşım:

Kalkınma

Ajansları

Üzerinde

COBIT-5 ile

Analiz ve

Modelleme

araştırma sonucunda kanıtlanmıştır. (Maříková, Rolínek, Kubecová, \& Vrchota, 2015, s. 110)

Maalesef, geleneksel iş süreçleri yönetim (BPM) sistemleri gündelik belirsizliklerle karşılaşan kurumların problemlerine çözüm getirememektedir. Örneğin, bilişim sistemlerinin hata vermesi veya yeni piyasa değişiklikleri ki kurumsal amaçları etkileyebilecek düzeyde de gerçekleşebilmektedirler. Bu belirsizlikle ve kurumsal ölçekteki etkileri aslında genel ismiyle risk olarak bilinmektedirler ve bunların doğru ilkeler, çerçeveler ve süreçlerle yönetilebilmeleri gerekir. Süreçlerde meydana gelen risklere karşı duyarlı olabilen sistemlere de risk-duyarlı süreç yönetimi (R-BPM) adı verilmektedir (Suriadi, et al., 2014). Süreç yönetiminin risk yönetimi ile entegre bir şekilde yönetilmesine olanak sağlayan ve bilişim ile iş süreçlerini entegre etmeyi hedefleyen bir çerçeve olarak COBIT-5 standardı ön plana çıkmaktadır.

Bulut bilişimin yükselişi ile birlikte kurumlar artık günümüzde hızlı bir şekilde bilişim ile ilgili süreçleri ve kaynaklarını değiştirmeye çalışmaktadırlar. Sadece bireysel uygulamalar değil aynı zamanda tüm iş süreçleri artık bulut ortama taşnabilmektedir (Stefan Schulte, Venugopal, Weber, \& Hoenisch, 2015). Bu tür gelişmeler bilişim süreçleri içe iş süreçlerinin entegrasyonu ve uyumlulaştırılması ihtiyacını da birlikte gündeme getirmiştir. 26 adet kalkınma ajansları (KA) yönetim bilgi sisteminin (YBS) kendi sunucularında değil, merkezi olarak bulut ortamda tutuluyor olması buna örnek olarak verilebilir. Buna benzer değişimler de aslında süreç yönetiminin de bulut bilişim kaynaklarını kullanarak zamanla elastik hale gelmesine yol açacaktır. Bu durum iş süreçlerinin bilişim süreçleri ile entegre bir şekilde yönetilmesine olanak sağlayan COBIT-5 uygulamaları açısından dikkate alınabilmesine olanak tanımaktadır.

Bir paradigma olarak dikkate alınabilecek olan COBIT, önceleri denetim, kontrol ve daha sonra yönetim çerçevesi iken daha sonraları risk ve katma değer ile ilgili standartları da bünyesine alarak zamanla bir BT yönetişim çerçevesi haline gelmiştir. COBIT- 5 çerçeve yaklaşımı 5 temel ilke "principles" getirmektedir. Bu ilkeler çerçevenin esas sütunlarını teşkil etmektedirler. Bu ilkeler üzerinde yapılacak olan yapısal kurgu ve süreç uygulamaları da gerçekleştiriciler "enablers" vasıtasıyla temellendirilebileceklerdir. 


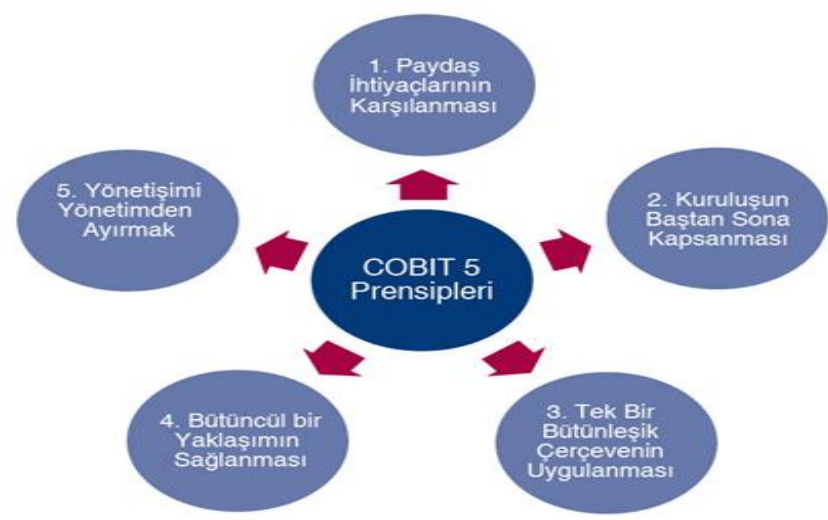

Şekil 1. COBIT-5 Temel İlkeleri

Kaynak: (ISACA, 2012)' den alınmıştır.

Şekilde görüldüğü gibi COBIT-5 beşinci versiyonunda beş temel ilke üzerinde kurulmuş oluştur. COBIT-5, sistem teorisinin temel varsayımlarını kullanarak birbiriyle etkileşim içerisindeki bileşkeleri dikkate alarak bütüncül bir yaklaşım sergilenmesi gerektiğini ortaya koymaktadır. Buna göre, gerçekleştiriciler kurumsal yönetişim ve yönetim açısından birbirini bütünleyen, diğer çerçeve ve standartların eksikliklerini tamamlayan, kurumun varlığını sürdürmesi için gerekli olan alt sistemlerden oluşan canlı bir sistemin birliğini tamamlamaktadır. (ISACA, 2012)

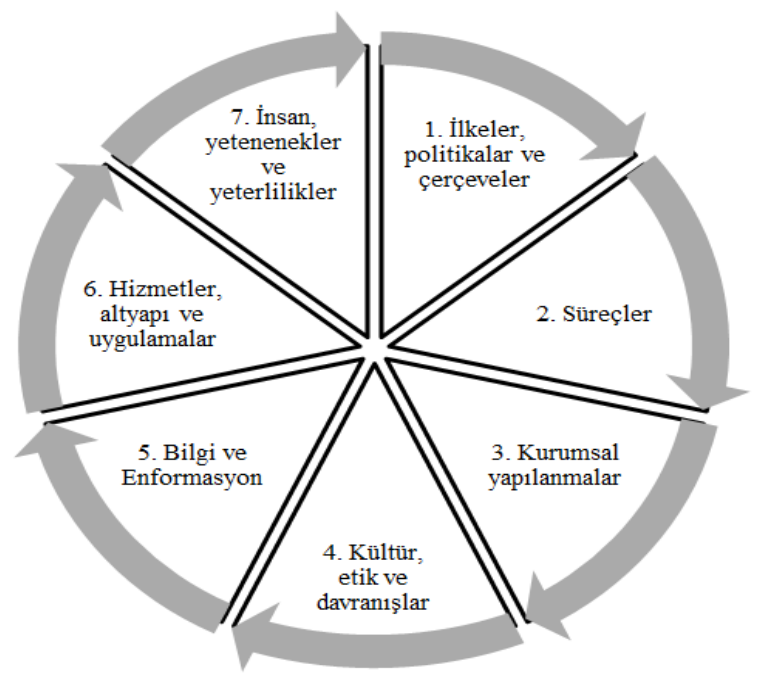

Şekil 2. COBIT-5 Gerçekleştiricileri

Kaynak: (ISACA, 2012)' den uyarlanmıştır.

Paradigma gerilimi, diğer standart ve çerçevelerin mevcut teknik ilişkiler ağını, gereklilikleri ve sürdürülebilir stratejik yönetimi acımasız rekabet ortamında açılayamaması ve çözüm bulamamasından dolayı
Kamu

Sektöründe

Süreç

Yapılandırma-

sina Teknik

Bir Yaklaşım:

Kalkınma

Ajansları

Üzerinde

COBIT-5 ile

Analiz ve

Modelleme 
Kamu

\section{Sektöründe}

Süreç

Yapılandirmasina Teknik

Bir Yaklaşım:

Kalkınma

Ajansları

Üzerinde

COBIT-5 ile

Analiz ve

Modelleme

ortaya çıkmıştır. Çünkü her kurumun paydaşları ve ihtiyaçları farklı olduğundan ve kaynakları ile riskleri de aynı olmadığından kendilerine has uyarlamaların yapılabilmesi aşikâr bir halde belirginleşmiştir. Kendisini çevresel koşullara ve zamanın gereklerine göre sürekli adapte edebilen COBIT bu gerilim içerisinde yeni bir paradigma olarak ortaya çıkarak mevut sorunlara çözüm sunma iddiasındadır.

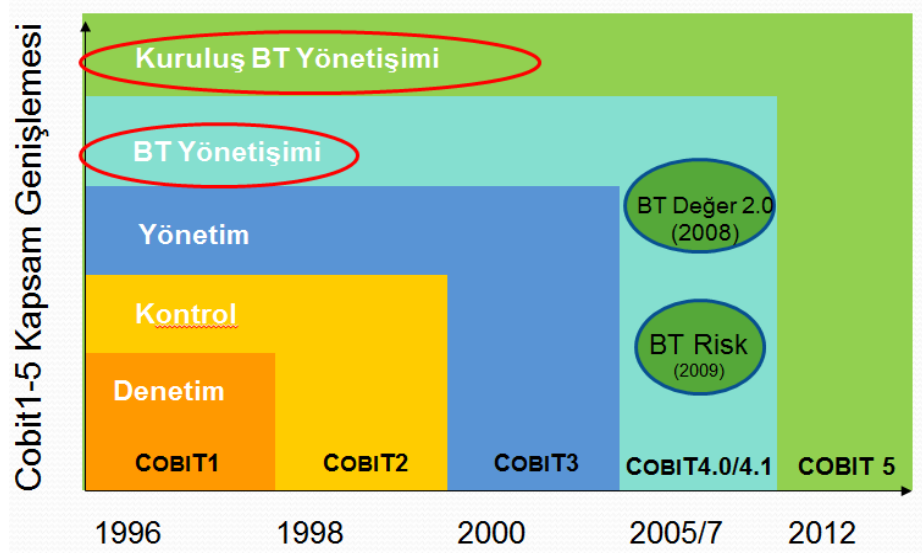

Şekil 3. COBIT Alanında Paradigma Gerilimleriyle Yaşanan Kapsam Genişlemesi

Kaynak: (ISACA, 2012)' den alınmıştır.

Şekilden de görüleceği üzere, COBIT-4 iş süreçlerini BT süreçleri ile hizalandırmak için bazı araçların geliştirilmesiyle ortaya çıkmış ve diğer yönetişim çerçeveleri ve BT çerçeve ve standartları ile olan ilişkileri de güçlendirmiştir. COBIT-5 gerçekleştiricileri bütüncül yaklaşımı esas alınarak BT ve iş süreçleri ile birlikte bir kurumsal anlamdaki her şey gerçekleştiriciler kapsamına alınabilmektedir. COBIT-5, ISACA tarafından geliştirilen bir BT yönetişim çerçevesidir. Şekilden de görüleceği üzere, COBIT, ilk başta finansal ve BT denetim ve kontrol alanlarında ilk önce kendisini göstermişti. İlk baştaki COBIT, "Control Objectives of IT" olarak bilinmekteydi. Daha sonra COBIT, göstergeler, süreç araçları, kritik başarı faktörleri, olgunluk modelleri ve BT yönetimi ile ilgili görev ve sorumluluklarının yerine getirilebilmesi için geliştirilen araçlarla birlikte aşamalı bir şekilde toplumsal ve ekonomik koşulların sonucu olarak yeni olarak elde edilen bilgilerle girdiği paradigma gerilimleri sonucunda bir yönetişim ve yönetim çerçevesi haline gelivermiştir. Bu durum elbette de BT ile ilişkili olan iş süreçleri ve sorumluluklarının katma değer oluşturma (Val IT) ve risklerin yönetilmesini (Risk IT) de belirlemiştir. Val IT ile Risk IT temel kavram ve süreçleri COBIT alanından alırken bunlara ilgili oldukları alanlara ait özel rehberlikler eklemişlerdir. 


\section{METODOLOJİ}

Araştırma yöntemi olarak literatür taraması, sorun analizi, mantıksal ilişkilendirme ve uyarlama gibi yöntemler kullanılmıştır. Literatür taraması EBSCO veri tabanı üzerinden yerli ve yabancı makaleler üzerinden yapılmıştır. Ebsco veri tabanında "process management" olarak yapılan taramada 9.720 adet olarak tespit edilen toplam araştırma sayısı içerisinde 159 adedinin Türkçe literatür kapsamında yapılan araştırmalar olduğu görülmüştür. Gene "COBIT-5" olarak yapılan taramada ise toplamda 125 olarak tespit edilen araştırmalar içerisinde sadece 1 tanesinin Türkçe literatür kapsamında olduğu anlaşılmıştır. $\mathrm{Bu}$ kapsamda değerlendirildiğinde yaptığımız araştırmanın Türkçe literatüre katkısı açısından önemli olduğu söylenebilir.

$\mathrm{Bu}$ çalışmamıda, COBIT-5 çerçevesinde uygulama gerçekleştiricileri olan yedi adet bileşen içerisinden süreçler gerçekleştiricisinin KA düzlemine uyarlanması yapılmaktadır. $\mathrm{Bu}$ kapsamda öncelikle COBIT-5 süreçler gerçekleştiricisi üzerinde betimleyici bir çalışma yapılmakta daha sonra KA sistematiğine uygulanması durumunda nasıl bir tablo ortaya çıtığ 1 anlaşılmaya çalışılmaktadır. Bu çalışmamızda ayrıca bazı sorunlar üstünde kök neden analizleri yapılarak süreç yapılandırmasıyla ilişkilendirilmektedir. Bu çalışmada kalkınma ajanslarının hedef basamaklarının kullanımıyla ilişkili olabilen sorunları analiz edilmektedir bu amaçla da DDK raporu incelenmiş ve süreç olgunluğu ile ilgili 2 adet probleme dair çekirdek neden analizleri yapılmaktadır. Hizmete özel olan DDK raporu üzerinde akademik araştırma yapılarak bu alandaki idari bilgi literatüre kazandırılmaktadır.

Araştırmamızda aşağıdaki sorulara cevap aranmaktadır:

1. DDK tarafından tespit edilen sorunlardan KA süreçlerinin doğru yapılandırılmaması ile ilişkili olan sorun var mıdır? Varsa hangileridir ve nasıl ilişkilendirilebilmektedir?

2. COBIT-5 süreç gerçekleştiricisi nedir ve KA dinamiklerinde nasıl uygulanabilir?

Yukarda ifade edilen araştırma sorularının cevaplanabilmesi için öncelikle KA dinamiklerinde DDK tarafından tespit edilen 43 sorundan sadece 2 tanesi analiz edilerek süreç yönetimi kurulumu ile ilgili olup olmadıkları üzerinde kök neden analizleri yapılmakta ve COBIT-5 süreç gerçekleştiricisi betimleyici bir araştırma yöntemi kullanılarak tanıtılmakta ve paydaşlar, kurumsal hedefler, süreç yönetimi yaşam döngüsü ve iyi uygulamalar çerçevesinde KA dinamiklerinde uygulanabilirliği analiz edilmektedir. Sonuçta ise bir kamu kurumu olarak KA sisteminde süreç
Kamu

Sektöründe Süreç

Yapılandırma-

sina Teknik

Bir Yaklaşım:

Kalkınma

Ajansları

Üzerinde

COBIT-5 ile

Analiz ve

Modelleme 
Kamu

Sektöründe

Süreç

Yapılandirmasina Teknik

Bir Yaklaşım:

Kalkınma

Ajansları

Üzerinde

COBIT-5 ile

Analiz ve

Modelleme

yönetiminin uygulanabilirliği ve mevcut sorunların kök nedenlerinin ortadan kaldırılmasındaki rolü üzerinde değerlendirme yapılmaktadır.

\section{ARAŞTIRMA PROBLEMI}

$\mathrm{Bu}$ araştırmamızda Devlet Denetleme Kurulu (DDK) tarafından 2014 yılında kalkınma ajanslarının (KA) 43 adet önemli sorunları olduğu yönünde hazırlanan araştırma raporundaki tespitlere dayanmaktadır. Buna göre çoğu sorunun aslında KA süreçlerinin işletilmesiyle doğrudan veya dolaylı bir şekilde ilişkili olduğu tespit edilmiştir. Örnek olarak sadece iki adet sorun ile ilgili kök neden analizleri aşağıda yapılmaktadır. $\mathrm{Bu}$ analizde karşılaştırmalı olarak COSO ve COBIT modelleri kullanılmıştır.

\subsection{Bağımsız Değerlendiricilerin Seçim ve Değerlendirme Usulleri Yetersizliği}

KA tarafından hibe verilen projelerin bağımsız değerlendirmesi aşamasında, bağımsız değerlendiricilerin iş deneyimleri ve uzmanlık alanları açısından değerlendirme yaptıkları projelere yatkınlıklarının aranması ve bağımsız değerlendirici tercihlerinde mali destek programının niteliğine göre seçici olunması, bağımsız değerlendiricilerin projelere ilişkin bölümler itibariyle verdikleri puanların gerekçelerini, konuya ilişkin yorumlarını ve projeye ilişkin riskleri, düzenledikleri değerlendirme raporlarında açık ve detaylı şekilde belirtmelerinin önem taşıdığ değerlendirilmektedir (DDK, et al., 2014).

Tablo 1. Değerlendiricilerin Seçim ve Değerlendirme Usulleri Yetersizliği Sorunu İçin Eylem Planları ve Kök Neden Analizi

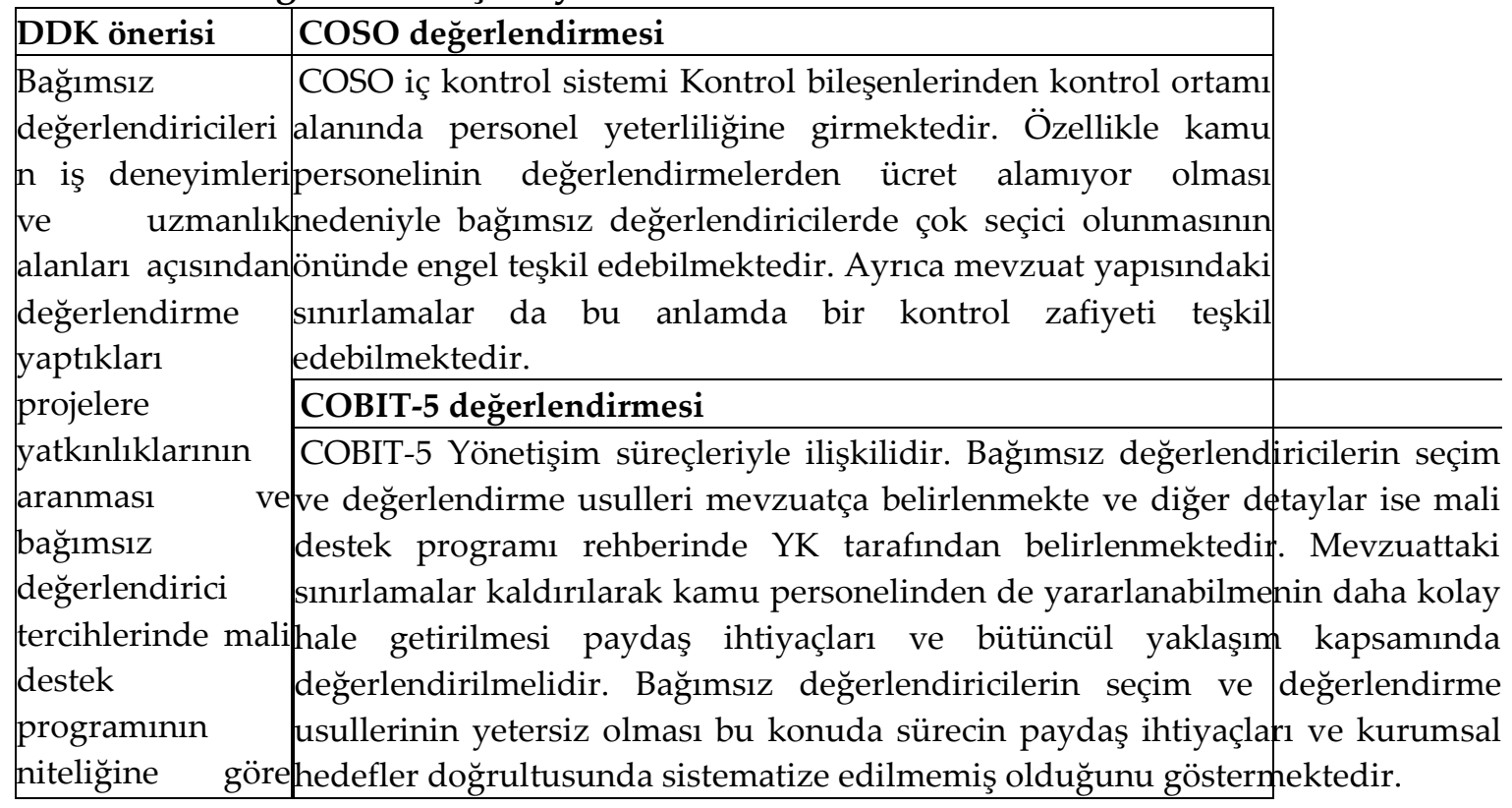


İsletme Bilimi Dergisi (JOBS), 2016; 4(2): 1-52. DOİ: 10.22139/jobs.287244

seçici olunması.

Kamu

Sektöründe

Süreç

Yapılandırma-

sina Teknik

Bir Yaklaşım:

Kalkınma

Ajansları

Üzerinde

COBIT-5 ile

Analiz ve

Modelleme

9 
Kamu

\section{Sektöründe}

Süreç

Yapılandırma-

sina Teknik

Bir Yaklaşım:

Kalkınma

Ajansları

Üzerinde

COBIT-5 ile

Analiz ve

Modelleme

\section{Tablo 1 Devamı}

\section{0}

\begin{tabular}{|c|c|}
\hline KB Eylem Planı & KA Eylem Planı \\
\hline 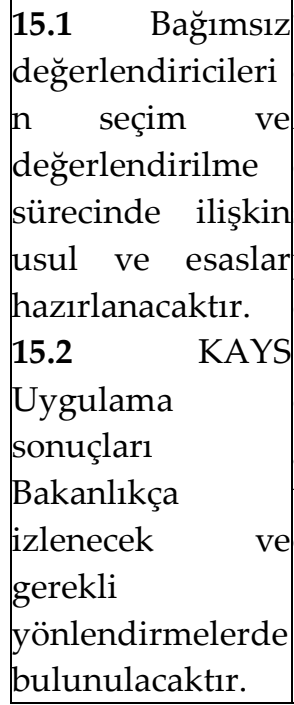 & $\begin{array}{l}\text { 15.3 Bağımsız değerlendirici seçiminde adaylara uygun iş } \\
\text { deneyimleri ve uzmanlık alanlarına sahip olması gözetilecektir. } \\
\text { Ajanslarda yürürlükte olan bağımsı değerlendirici seçim ve } \\
\text { değerlendirme süreçlerinde risk kontrol noktaları ve kontrol } \\
\text { sayıları artırılacaktır. Bir projenin değerlendirilmesi için sadece o } \\
\text { projenin sektörüne ve NACE koduna uygun bağımsız } \\
\text { değerlendiriciler arasından rastgele atama yapılacaktır. } \\
\text { 15.4 Değerlendirmelerde verilen puanların gerekçelerinin } \\
\text { detaylı yer alması hususu gözetilecektir. Bunu } \\
\text { gerçekleştirmeyen değerlendiricilere yönelik yaptırım } \\
\text { uygulanacaktır. Bağımsı değerlendirme sürecine başlanmadan } \\
\text { önce değerlendiricilere kapsamlı eğitim verilecektir }\end{array}$ \\
\hline
\end{tabular}

Kaynak: (DDK, et al., 2014) ve (KB-BGYUGM, 2014)'dan yararlanarak araştırmacı tarafından oluşturulmuştur.

\subsection{Bütçe Revizyonlarında Ölçüsüzlük}

DDK tarafından yerelde yapılan araştırma ve inceleme çalışmaları sırasında, herhangi bir inceleme veya fiyat araştırması yapılmadan projelerin bütçe kalemlerinde indirim şeklinde revizyonlar yapılabildiği ve ajanslar arasında bütçe revizyonu aşamasında değişik standartların uygulandığ1 görülmüştür. 2009-2012 dönemi için tüm ajansların bütçe revizyonu ortalamasının \%16 olduğu, aynı zamanda ajanslar arasındaki farkların da önemli boyutlarda bulunduğu, bazı ajanslarda bütçe revizyon oranın \%46'ya kadar ulaştığı anlaşılmıştır. (DDK, et al., 2014) 
Tablo 2. Projelerin Bütçe Revizyonlarında Ölçüsüzlük Sorunu İçin

Kamu

Eylem Planları ve Kök Neden Analizi

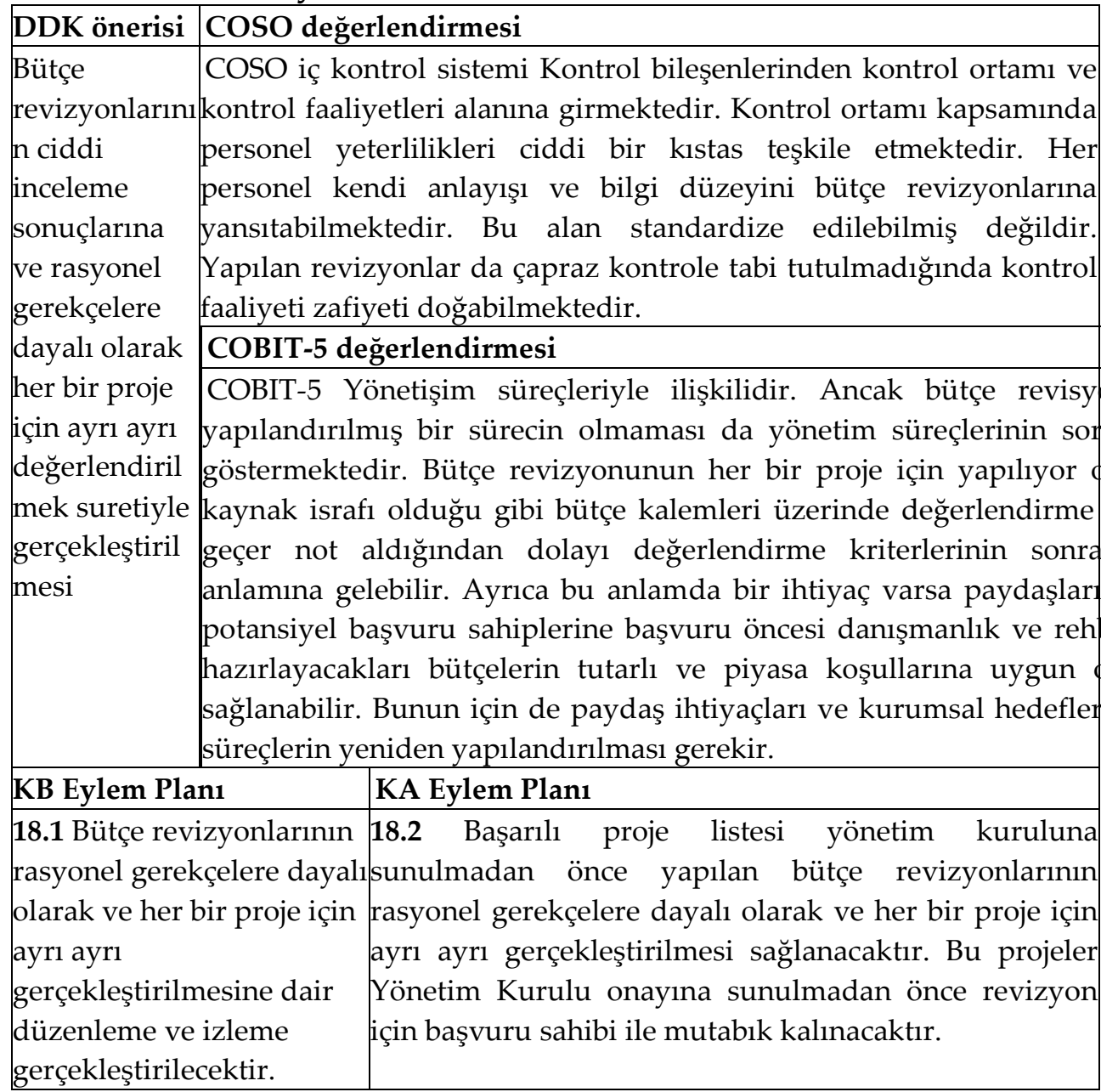

Kaynak: (DDK, et al., 2014) ve (KB-BGYUGM, 2014)'dan yararlanarak araştırmacı tarafından oluşturulmuştur.

Yukarıdaki analizlerden de anlaşılacağı üzere KA süreçlerinin ve süreç yönetim sisteminin sorunlu olduğu "Değerlendiricilerin Seçim ve Değerlendirme Usulleri Yetersizliği" ile "Bütçe Revizyonları" süreçlerinden anlaşılmaktadır. Bu iki sorun örnek olarak ele alınmıştır. Ve bu konudaki analiz ve tespitler de tümevarımsal bir mantıksal yaklaşımla genel olarak KA süreç yönetiminde bir soruna işaret ettiği söylenebilmektedir. Bu nedenle de bu sorunun çözümlenebilirliği süreçlere bütüncül olarak bakarak her süreçteki çıtıların başka süreçlere girdi olarak modelleyen COBIT-5 standardı çerçevesinde tartışılacaktır. Bunun için de öncelikle 7 adet gerçekleştiriciden birisi olan süreçler gerçekleştiricisinin COBIT-5 çerçevesindeki tanımı yapıldıktan sonra KA dinamiklerine uyarlanabilirliği tartışılacaktır. 
Kamu

\section{Sektöründe}

Süreç

Yapılandırmasina Teknik

Bir Yaklaşım:

Kalkınma

Ajansları

Üzerinde

COBIT-5 ile

Analiz ve

Modelleme

12

\section{SÜREÇLER GERÇEKLEŞTiRicisi}

Süreç, "genel olarak, çeşitli kaynaklardan (diğer süreçler de dâhil olmak üzere) girdi alan, girdileri işleyen ve çıtı üreten (örneğin, ürünler, hizmetler), kuruluşun politikaları ile usullerinden etkilenen bir uygulamalar bütünü" biçiminde tanımlanmaktadır.

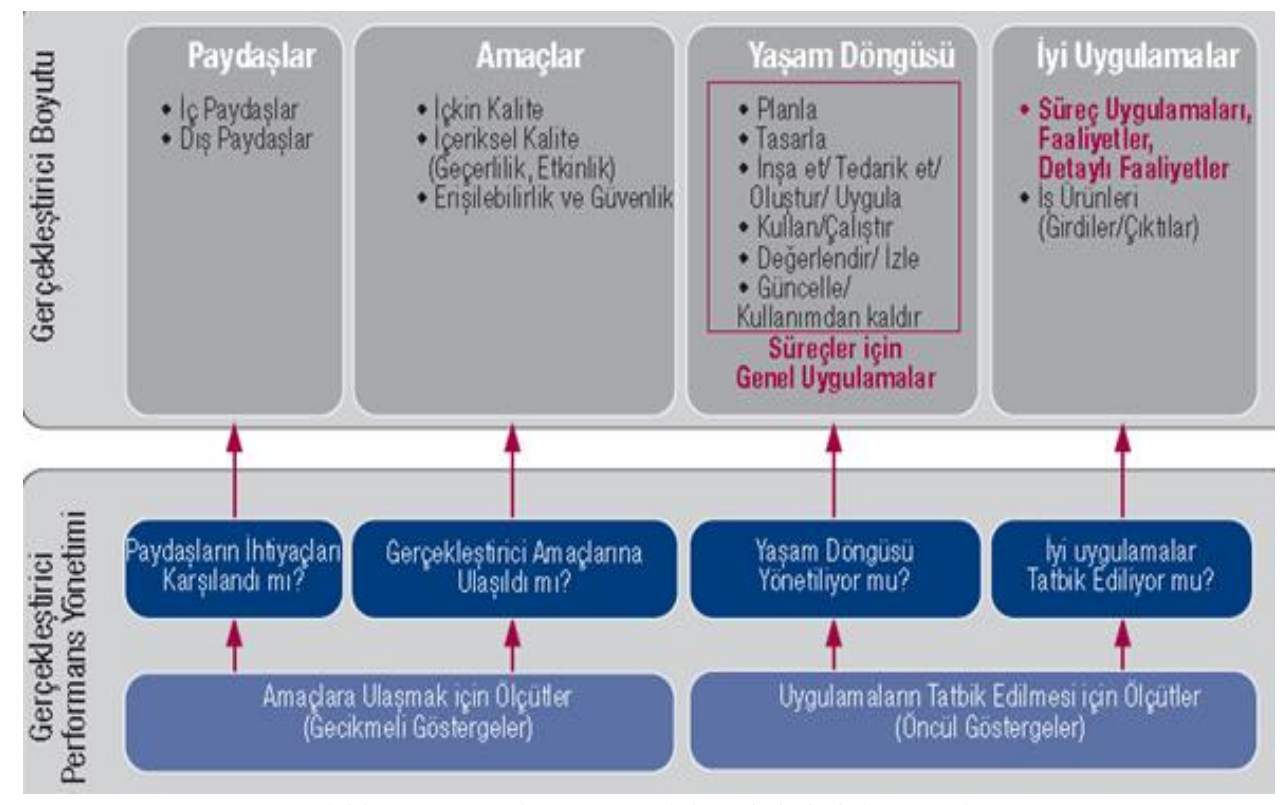

Şekil 4. Süreçler gerçekleştiricisi boyutları

Kaynak: (ISACA, 2012)' den alınmıştır.

COBIT-5 çerçeve olarak uygulanabilirliğini 5 ilke ile 7 gerçekleştiriciye bağladığından bir gerçekleştirici olarak süreçler de bu kapsamda ele alınmaktadır. Süreç modelinin gerçekleştirici boyutu da ilkeler, politikalar ve çerçeveler gerçekleştiricisinde olduğu gibi; paydaşlar, hedefler, yaşam döngüsü ve iyi uygulamaları içermektedir:

\subsection{Paydaşlar}

Süreçlerde kendi görevleri olan iç ve dış paydaşlar vardır; paydaşlar ve sorumluluk seviyeleri, kimin sorumlu, mesul, danışılan veya bilgilendirilen (SMDB) olduğunu gösteren tablolarda belgelenir. (ISACA, 2012) Dış paydaşlara vatandaş, paydaş, yararlanıcı ve yatırımcılar, KK üyeleri ile düzenleyiciler kategorisinde $\mathrm{KB}$ yetkilileri dâhildir. İç paydaşlara yönetim kurulu, yönetim ve personel dâhildir. Dolayısıyla süreçlerdeki paydaşların rolleri gereği gerekli katkıyı sağlamaları için sürece dâhil edilmeleri sağlanmalıdır. 


\subsection{Hedefler}

Süreç hedefleri "bir sürecin istenilen sonucunu açıklayan bir ifade" olarak tanımlanır. Sonuç bir ürün, önemli bir durum değişikliği veya diğer süreçlere dair önemli bir yetenek geliştirmesi olabilir. Bunlar hedef basamaklarının bir kısmını oluşturur, yani süreç hedefleri BT-bağlantılı hedefleri destekler, BT-bağlantılı hedefler de kalkınma ajansının kurumsal hedeflerini ve bunlar da paydaşların ihtiyaçlarını destekler. (ISACA, 2012) Süreç hedefleri aşağıdaki şekilde sınıflandırılabilir:

\section{Asli Süreç Hedefleri}

Asli hedef, özgün hedefleri ifade etmektedir. O sürecin bizzat hizmet ettiği varlık amacını açıklayan hedefler asli veya özgün hedeflerdir. Süreç asli kaliteye sahip mi? Doğru mu ve iyi uygulamalarla uyumlu mu? İç ve dış kurallara uygun mu? Gibi soruların cevaplandığ $\breve{1}_{1}$ ölçüde asli ve özgün hedeflerin kalitesi anlaşılır (ISACA, 2012).

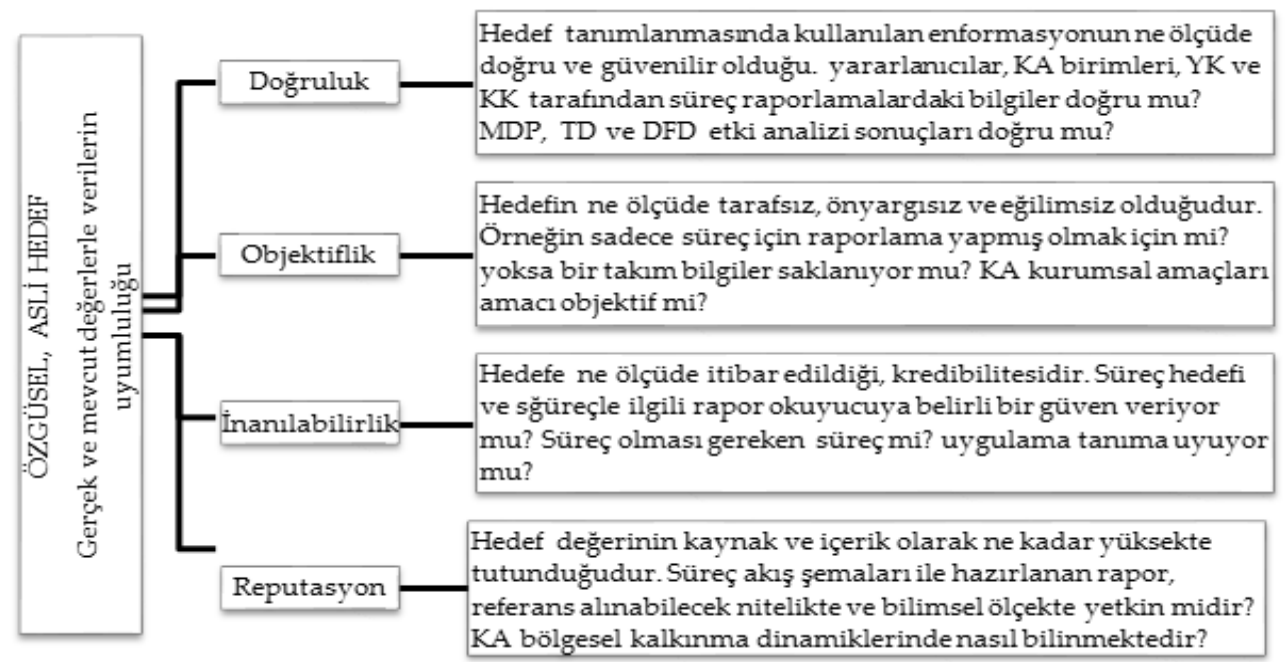

Şekil 5. Özgün ve Asli Hedef Amaç/Kalite Kriterleri Modeli

Kaynak: (ISACA., 2012a)' dan esinlenen Araştırmacı tarafından hazırlanmıştır.

\section{İçeriksel Süreç hedefleri}

Süreç, her KA özel durumuna göre, her birimin işleyiş̧ine göre, her personelin yetkinlik ve aldığı eğitimlere göre özelleştirildi ve uyarlandı mı? Süreç konuyla ilgili, anlaşılır, uygulanması kolay mı? Gibi sorulara tam cevap verdiği ölçüde içeriksel hedeflerin kalite kriterlerinin yerine getirildiği söylenebilir. (ISACA, 2012)
Kamu

Sektöründe

Süreç

Yapılandırma-

sina Teknik

Bir Yaklaşım:

Kalkınma

Ajansları

Üzerinde

COBIT-5 ile

Analiz ve

Modelleme 


\section{Kamu}

\section{Sektöründe}

Süreç

Yapılandirmasina Teknik

Bir Yaklaşım:

Kalkınma

Ajansları

Üzerinde

COBIT-5 ile

Analiz ve

Modelleme

14

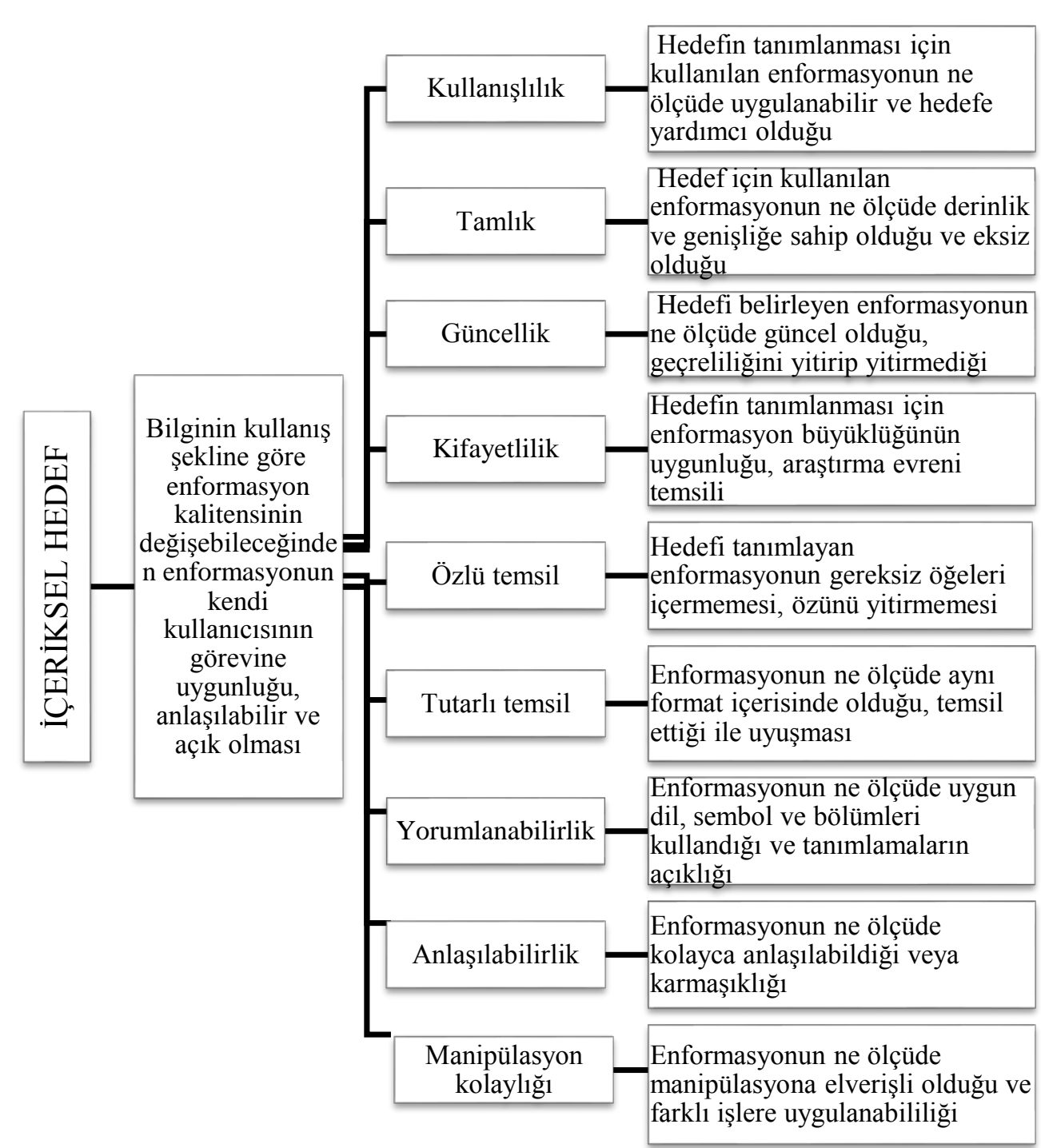

Şekil 6. İçeriksek Hedef Amaç/Kalite Kriterleri Modeli

Kaynak: (ISACA., 2012a)' dan esinlenen araştırmacı tarafından hazırlanmıştır.

\section{Süreçlerin Erişilebilirlik ve Güvenlik Hedefleri}

Süreç gerektiğinde gizli olarak kalır ve ihtiyacı olan kişi tarafından bilinir ve erişilebilir. Ölçütler, hedeflere ne ölçüde ulaşıldığını ölçmek amacıyla hedef basamaklarının her seviyesinde, dolayısıyla süreçler için de tanımlanır. Ölçütler, "bir süreç hedefine ulaşmanın ölçülmesini sağlayan ölçülebilir bir niteliktir" şeklinde tanımlanabilir. Aşağıdaki şemada erişilebilirlik ve güvenlik hedeflerine dair kriterler yer almaktadır (ISACA, 2012). 


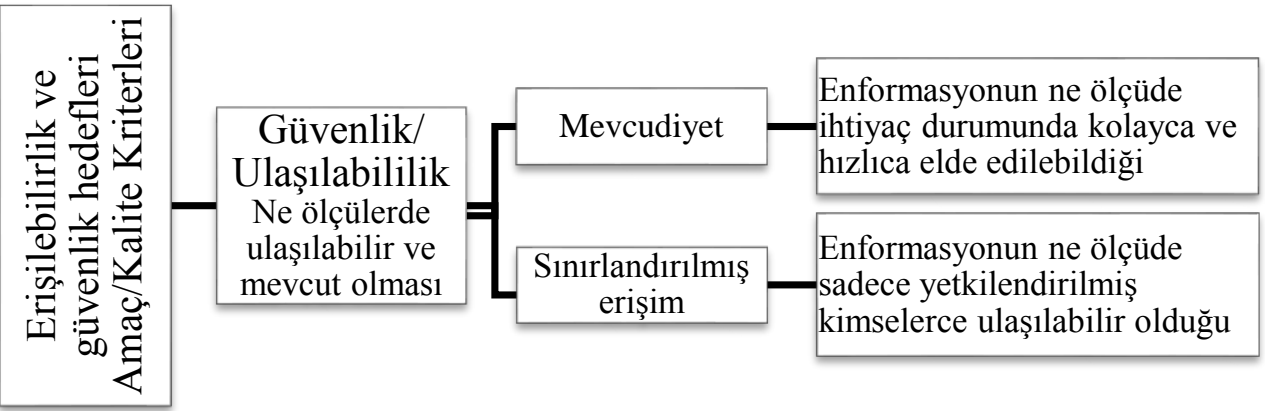

Şekil 7. Erişilebilirlik ve Güvenlik Amaç/Kalite Kriterleri Modeli

Kaynak: (ISACA., 2012a)' dan esinlenen araştırmacı tarafından hazırlanmıştır.

Ölçütler, SMART- özgün, ölçülebilir, uygulanabilir, konuyla ilgili ve güncel olmalıdır. Gerçekleştiriciyi etkili ve verimli şekilde yönetmek için, ölçütlerin, beklenen sonuçların ne ölçüde gerçekleştirildiğini ölçmek amacıyla tanımlanması gerekir. Ek olarak, gerçekleştirici performans yönetiminin ikinci safhasında, iyi uygulamaların ne ölçüde uygulandığ açıklanır. İlişkili ölçütler, gerçekleştirici yönetimine yardımcı olmak amaciyla burada da tanımlanabilir.

\subsection{Yaşam Döngüsü}

Her sürecin yaşam döngüsü vardır. $B u$ döngüde süreçler; tanımlanır, oluşturulur, yürütülür, izlenir ve ayarlanır/güncellenir veya sonlandırılır. Bu döngü genel süreç uygulamaları, süreçlerin tanımlanması, yürütülmesi, izlenmesi ve optimizasyonuna yardımcı olabilir. COBIT-5 uygulamasının da bir yaşam döngüsü vardır. Bu yaşam döngüsünün de belirli aşamalar dâhilindeki süreçler olarak uygulanması olanaklıdır. Aşağıda uygulama yaşam döngüsünün yönetilmesi kısmında COBIT-5 uygulama döngüsünden bahsedilecektir. (ISACA, 2012)

COBIT-5 sistematiğinin KA dinamiklerinde uygulanabilmesi için yaşam döngüsü yaklaşımı (ISACA., 2012a) benimsenmiştir. Yaşam döngüsünün uygulanması, uygulama sırasında karşılaşılan karmaşıklıklara ve tipik zorluklara COBIT-5 kullanarak hitap etme olanağ1 sağlar. Yaşam döngüsünün birbiriyle ilişkili üç bileşeni şunlardır:

a) Tek seferlik bir proje olmadığından yaşam döngüsünün sürekli geliştirilmesi

b) Davranışsal ve kültürel boyutlara değişime olanak tanıma
Kamu

Sektöründe

Süreç

Yapılandırma-

sina Teknik

Bir Yaklaşım:

Kalkınma

Ajansları

Üzerinde

COBIT-5 ile

Analiz ve

Modelleme 
Kamu

\section{Sektöründe}

Süreç

Yapilandirmasina Teknik

Bir Yaklaşım:

Kalkınma

Ajansları

Üzerinde

COBIT-5 ile

Analiz ve

Modelleme

16 c) Programın yaşam döngüsü çerçevesinde yönetimi

Uygulamanın başarısı ya da girişimin gelişmesini garanti altına almak için uygun ortam oluşturulmalıdır. (ISACA., 2012a) Bu çalışmanın tamamen uygulanması noktasında uygun ortamın (mevzuat değişikliği, yönetim iradesi, uygulayıcıların eğitimi) henüz mevcut olmadığı tespit edilmiş ve bu aşağıdaki şekilde yaşam döngüsü ve yedi aşaması gösterilmiştir. 6. Aşamadaki kar gerçekleştirme kamu sektörü kapsamında olan KA için "bölgesel kalkınmayı sağla" şeklinde uygulanmıştır.

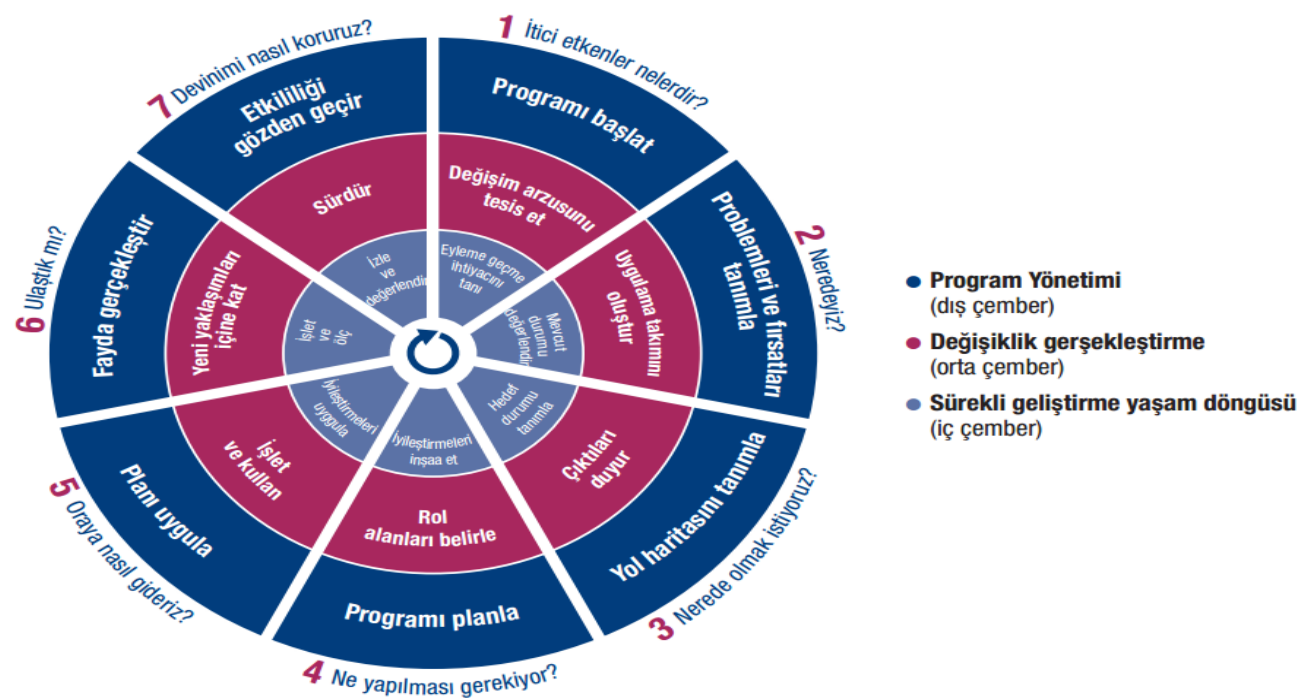

Şekil 8. COBIT-5 Uygulama Yaşam Döngüsünün Yedi Aşaması Kaynak: (ISACA, 2012)' den alınmıştır.

\section{Aşama 1: İtici etkenler nelerdir?}

Birinci aşama, mevcut itici etkenleri tanımlar ve daha sonra basit bir olurluk incelemesi taslağına dönüşmek üzere üst düzey yönetici seviyeleri için bir değişim isteği yaratır. Bir değişim iticisi, değişim için bir destek görevini gören iç ya da dış bir olay, durum ya da anahtar konudur. Olaylar, eğilimler (endüstri, pazar ya da teknik), performans düşüklükleri, yazılım uygulamaları ve hatta kurumun amaçları itici etken rolü oynayabilir. Programin uygulanmasıyla ilgili riskler olurluk incelemesinde tanımlanacak ve yaşam döngüsü boyunca yönetilecektir. Bir olurluk incelemesinin hazırlanması, sürdürülmesi ve izlenmesi, KBTY iyileştirmesi de dâhil olmak üzere herhangi bir girişimdeki başarılı çıtıların gerekçelenmesi, desteklenmesi ve garanti altına alınması için temel ve önemli disiplinlerdir. Bunlar programın faydaları üzerinde sürekli bir odaklanma ve onların gerçekleştirilmesini sağlarlar. (ISACA., 2012a, s. 20) 
Bir uygulamaya ya da bir iyileştirme girişimine ihtiyaç olduğunu tanıma ve bu konuda anlaşma ile başlar. Bu aşama, mevcut sancılı noktaları ve tetikleyicileri tanımlayarak üst yönetim seviyesinde bir değişim isteği oluşturur. Bu sancilı noktalar ve tetikleyici olayların DDK raporunda yeterince belirtildiği düşünülmektedir. Ancak normal uygulamada mutlaka tetikleyici faktörlerin tespit edilmesi gerekir. Dış çember olan program yönetimi kısmında bu uygulama bir program uygulaması olarak kabul edilmesi gerekliliğinden hareket etmektedir.

COBIT-5

uygulaması birçok projeyi barındıran bir program uygulamasıdır. $\mathrm{Bu}$ nedenle de program başlatıldıktan sonra orta çemberde değişim arzusunun tesis edilmesi gerekir. $\mathrm{Bu}$ değişim arzusu olmaksızın doğrudan uygulanamaz. COBIT-5 bir değişim ve dönüşüm gerektireceğinden dolayı yönetişim mekanizmasının bunu bir ihtiyaç olarak görmesinden sonra iç ve dış paydaşlarda bu değişim arzusunun tesis edilmesi gerekmektedir. İç çemberde ise eyleme geçme ihtiyacının tanınması gerekmektedir. Bunun bir ihtiyaç olarak görülmesi bu anlamda uygulamanın kolaylaşması ve kökleşmesine yardımcı olmaktadır.

COBIT-5 yaşam döngüsünde ilk ele alınması gereken en dış çember "uygun ortamın oluşturulması" kapsamındaki "itici etkenler nelerdir" sorusuna cevap verecek şekilde zorluklar ile başarı faktörleri aşağıdaki şekilde analiz edilebilmektedir:

Tablo 6. İtici Etkenlerdeki Kök Nedenler ve Başarı Faktörleri

\begin{tabular}{|c|c|}
\hline Zorluklar & $\begin{array}{l}\text { Üst yöneticilerin katkısının, bağlılığının ve desteğinin yokluğu. } \\
\text { Değer ve faydaların gösterilmesindeki güçlükler. }\end{array}$ \\
\hline $\begin{array}{l}\text { Kök } \\
\text { nedenler }\end{array}$ & $\begin{array}{l}\text { - İyileştirilmiş yönetişimin kurum için önemi, kaçınılmazlığı ve değerinin } \\
\text { anlaşılamaması (ya da bu yöndeki kanıtların eksikliği) } \\
\text { - KBTY kapsamının,ve BT yönetişimi ile BT yönetimi arasındaki farkların } \\
\text { yeterince anlaşılamaması } \\
\text { - Uygulamanın itici etkeninin iyileşme için önetkin ve geniş kapsamlı bir } \\
\text { gerekçelendirmeden ziyade bir probleme kısa vadeli bir tepki olarak ortaya } \\
\text { çıkması } \\
\text { - “Muhtemelen başarısız olacak başka bir proje” hakkındaki kaygılar - BT } \\
\text { yönetimine karşı güvensizlik } \\
\text { - Yönetişim konuları ve faydaları hakkında eksik iletişim- } \\
\text { açıkça belirtilmemiş faydalar ve zaman çerçeveleri } \\
\text { - Sponsorluk ya da sorumluluk için üst yöneticilerin istekli olmaması } \\
\text { - BT biriminin güvenirliğinin zayıf olduğu algısı-Yeterince saygı }\end{array}$ \\
\hline
\end{tabular}




\section{Kamu}

\section{Sektöründe}

Süreç

Yapılandirmasina Teknik

Bir Yaklaşım:

Kalkınma

Ajansları

Üzerinde

COBIT-5 ile

Analiz ve

Modelleme

18

uyandırmayan bir üst düzey BT yöneticisi

- Üst Yönetimin KBTY'nin sadece BT yönetiminin sorumluluğunda olması gerektiği yönündeki inanc1

- KBTY'den sorumlu olmaya uygun takım (ya da görev oyuncularının) olmaması ya da görevi üstlenmek için gerekli yetkinliklere sahip olunmaması

- Mevcut çerçevelerin bilgisizce kullanımı, eğitim ve farkındalık eksikliği

- Mevcut kurumsal yönetişim bağlamında KBTY'nin yanlış konumlandirılması

- Girişimin, kitaba uygun birebir örnekleri öneren "müritler" tarafından yönlendirilmesi

Başarı etkenleri
- KBTY'nin tartışılması için yönetim, denetim ve risk kurullarında bir gündem maddesi oluşturulması

- Eylemlere yetki ve sorumluluk sağlanması için bir kurul oluşturulması ya da hâlihazırda var olan BT yönetim stratejisi kurulu gibi yapıların güçlendirilmesi

- KBTY'yi "problem bulmaya çalışan" bir çözüm biçiminde görülmesinden kaçınılması — ortada gerçek bir ihtiyaç ve olası bir fayda olmalıdır

- Girişimin başarısı, güvenirliği ve anlaşılırlığı için yetki sahibi lider(ler)in ve sponsor(lar)in belirlenmesi

- Statükonun değiştirilmesi isteğini harekete geçirebilecek sancilı noktaların tanımlanması ve üzerinde konuşulması

- Hedef kitleye uygun dilin, yaklaşımların ve iletişim yollarının kullanılmasıhedef kitlenin yabancı olduğu kavram ve terimlerden kaçınılması

- $\mathrm{BT}^{\prime}$ den beklenilen değerin (iş birimleriyle) birlikte tanımlanması ve üzerinde anlaşılması

- Faydaların (üzerinde anlaşılmış) iş terimleriyle/ölçütleriyle ifade edilmesi

- Gerekiyorsa dış denetçilerden ya da danışman ve müşavirlerden destek alınması ve becerilerin arttırılması

- Dönüşüm çalışmasının atmosferini belirleyip zeminini hazırlayacak rehberlik ilkelerinin geliştirilmesi

- Kuruma özel dönüşüm çalışması temelinde zorunlulukların üretilmesi, başarı için gerekli güvenin ve ortaklığın inşa edilmesi

- Hedef kitlesine, önerilen BT yatırımının iş faydalarını göstermek için örnek bir olurluk incelemesinin tasarlanması

- Olurluk incelemesinde mevcut kurumsal sorunlu noktalara öncelik verilmesi ve olurluk incelemesinin stratejik odak ile hizalanması

- Olurluk incelemesinin genel kurumsal yönetişim amaçlarıyla hizalanması

- KBTY konuları ve çerçeveleri hakkında eğitim alınması ve uygulama yapılması 


\begin{tabular}{|c|c|}
\hline Zorluklar & $\begin{array}{l}\text { Gerekli iş birimlerinin katılımının sağlanmasında zorluk } \\
\text { Paydaşların ve görev oyuncularının tanımlanmasında zorluk }\end{array}$ \\
\hline $\begin{array}{l}\text { Kök } \\
\text { nedenler }\end{array}$ & $\begin{array}{l}\text { - KBTY'nin iş birimi yöneticileri için bir öncelik olmaması (anahtar performans } \\
\text { göstergesi(KPI) olmaması) } \\
\text { - BT yönetiminin izole biçimde çalışmayı tercih etmesi-“müşteri”yi dâhil } \\
\text { etmeden önce kavramın sağlanması Birlikte çalışmayı engelleyen BT ve iş } \\
\text { birimi arasındaki bariyerler } \\
\text { - İş biriminin katılımı için somut roller ve sorumlulukların bulunmaması } \\
\text { - Kilit iş birimi üyelerinin ve etkileyici kişilerin dâhil olmaması ya da } \\
\text { ilişkilendirilmemesi } \\
\text { - KBTY'nin faydaları ve iş değeri konusunda iş birimi yöneticilerinin ve süreç } \\
\text { sahiplerinin dar kapsamlı anlayışları }\end{array}$ \\
\hline Zorluklar & $\begin{array}{l}\text { Gerekli iş birimlerinin katılımının sağlanmasında zorluk } \\
\text { Paydaşların ve görev oyuncularının tanımlanmasında zorluk }\end{array}$ \\
\hline $\begin{array}{l}\text { Başarı } \\
\text { etkenleri }\end{array}$ & $\begin{array}{l}\text { - Üst yönetimin ve BT yönetim stratejisi kurulunun yetki verilmesi için teşvik } \\
\text { edilmesi; KBTY'deki iş rolleri ve sorumluluklar üzerinde ısrar edilmesi } \\
\text { - Paydaşların işin içine girmesi için süreçlerin işleme konulması } \\
\text { - İş faydalarının açkça anlatılması ve beğendirilmesi } \\
\text { - Katılım olmamasının riskinin açılanması } \\
\text { - İyileştirilmiş KBTY'ye iş biriminin dâhil olması için kritik hizmetlerin ya da } \\
\text { ana BT girişimlerinin tanımlanarak pilot/model olarak kullanılması } \\
\text { - Yandaşların bulunması-daha iyi bir KBTY'nin değerini anlayan iş birimi } \\
\text { çalışanlarının bulunması } \\
\text { - İyi tanımlanmış politikalar ve bir yönetişim yapısı içinde olmak kaydıyla } \\
\text { serbest düşünce ve yetkilendirmenin teşvik edilmesi } \\
\text { - İtici etkenlerden ve bunların değişiminden sorumlu olan kişilerin sponsor } \\
\text { desteği almasının sağlanması } \\
\text { - İş birimlerinin katılımı için tartışma ortamlarının oluşturulması (BT Yönetim } \\
\text { Stratejisi Kurulu gibi), mevcut sorunların ve iyileştirme fırsatlarının açıça } \\
\text { tartışılması için çalıştaylar düzenlenmesi } \\
\text { - Mevcut durum değerlendirmelerine yüksek düzey iş birimi temsilcilerinin } \\
\text { dâhil edilmesi }\end{array}$ \\
\hline Zorluk & BT yönetiminin iş kavrayışının eksik olması \\
\hline
\end{tabular}

Kamu

Sektöründe

Süreç

Yapılandirma-

sına Teknik

Bir Yaklaşım:

Kalkınma

Ajansları

Üzerinde

COBIT-5 ile

Analiz ve

Modelleme 
Kamu

\section{Sektöründe}

Süreç

Yapilandirmasina Teknik

Bir Yaklaşım:

Kalkınma

Ajansları

Üzerinde

COBIT-5 ile

Analiz ve

Modelleme

20

\begin{tabular}{|c|c|}
\hline $\begin{array}{l}\text { Kök } \\
\text { nedenler }\end{array}$ & $\begin{array}{l}\text { - Teknik işletme altyapısı kökenli BT liderliği-kurumsal iş konularına } \\
\text { yeterince dâhil olunmamış olması } \\
\text { - BT yönetiminin kurum içinde izole olması-üst seviyelere dâhil edilmemesi } \\
\text { - Zayıf iş ilişkisi süreci } \\
\text { - BT'yi ve üst düzey BT yöneticisini savunmacı bir iş yapma yoluna sokan } \\
\text { geçmiş düşük performans algısı • Saldırıya/tenkide açık üst düzey BT } \\
\text { yöneticisi ve BT yönetiminin iç zayıflıkları açılama konusunda isteksizlikleri }\end{array}$ \\
\hline $\begin{array}{l}\text { Başarı } \\
\text { etkenleri }\end{array}$ & $\begin{array}{l}\text { - Saygı duyulan BT çalışanlarının performansına ve başarısına dayandırılacak } \\
\text { bir güvenilirlik sağlanması } \\
\text { - BT yönetiminin yürütme kurulunun daimi bir üyesi olmasının sağlanması, } \\
\text { böylece iş hakkında uygun öngörü sahibi olması ve girişimlere erken dâhil } \\
\text { olması } \\
\text { - Etkili bir iş ilişkileri sürecinin uygulanması } \\
\text { - İs katılımının ve bağlılığının istenmesi. Deneyim kazanmaları ve iletişimin } \\
\text { iyileştirilmesi için iş birimi çalışanlarının BT’ye ve BT çalışanlarının iş } \\
\text { birimlerine yerleştirilmesinin değerlendirilmesi } \\
\text { - Gerek görülürse, BT yönetim rollerinin yeniden düzenlenmesi ve diğer iş } \\
\text { birimleriyle (mali birim ve İ gibi) resmi bağlantılar kurulması } \\
\text { - Üst düzey BT yöneticisinin iş birimi deneyimi olmasının sağlanması ve iş } \\
\text { birimlerinden atanmasının da değerlendirilmesi } \\
\text { - Daha güçlü bir iş merkezli KBTY stratejisi için danışmanlar kullanılması } \\
\text { - Daha iyi bir iş öngörüsü için BT içinde iş ilişkisi yöneticileri gibi yönetişim } \\
\text { mekanizmalarının yaratılması }\end{array}$ \\
\hline Zorluklar & $\begin{array}{l}\text { Geçerli bir kurumsal politika ve yönlendirmenin bulunmaması } \\
\text { Güncel kurumsal yönetişimin zayıflığı }\end{array}$ \\
\hline $\begin{array}{l}\text { Kök } \\
\text { nedenler }\end{array}$ & $\begin{array}{l}\text { - Organizasyonel gelişmemişlik ihtimalinden kaynaklı bağlılık ve liderlik } \\
\text { sorunları } \\
\text { - Mevcut kültürün otokratik olması, kurumsal politikalardan ziyade kişisel } \\
\text { emirlere dayanması } \\
\text { - Kültürün bir kontrol ortamından ziyade serbest düşünceyi ve resmi olmayan } \\
\text { yaklaşımları teşvik etmesi } \\
\text { - Kurumsal risk yönetiminin zayıf olması }\end{array}$ \\
\hline $\begin{array}{l}\text { Başarı } \\
\text { etkenleri }\end{array}$ & $\begin{array}{l}\text { - Zayıf yönetişim riskine yönelik konu ve kaygıların uyum ve kurumsal } \\
\text { performans temelinde yönetim kurulu seviyesindeki yöneticilerle (yönetici } \\
\text { olmayanlar da dahil olmak üzere) tartışılması }\end{array}$ \\
\hline
\end{tabular}




\begin{tabular}{|l|l|l|}
\hline - Sorunların Denetim Kurulu veya iç denetim birimi ile tartışılması \\
• Dış denetçilerden girdi ve rehberlik sağlanması \\
- Gelişmiş yönetişim becerileri kazanmak için kültürün nasıl \\
değiştirilebileceğinin düşünülmesi \\
• Üst düzey yönetici ve yönetim kuruluyla konuların görüşülmesi \\
- Kurum genelinde risk yönetiminin uygulanmasından emin olunması
\end{tabular}

Kaynak: (ISACA., 2012a) den alınmıştır.

\section{Aşama 2: Neredeyiz?}

İkinci aşama, BT-bağıntılı hedefleri kurumsal stratejiler ve risklerle hizalar; en önemli kurumsal amaçları, BT-bağıntılı amaçları ve süreçleri önceliklendirir. Seçimlere yardımcı olmak amacıyla, COBIT 5, kurumsal amaçlar ve BT-bağıntılı amaçlar ile BT süreçleri için genel bir eşleştirme sağlar. Seçilen kurumsal ve BT-bağıntılı amaçlar uyarınca, başarılı çıktıları sağlamak için yeterli yetkinlik seviyesini garanti altına alan gerekli kritik süreçler belirlenir. Yönetimin mevcut yetkinliğini ve nerelerde eksiklikler olduğunu bilme gereksinimi vardır. $\mathrm{Bu}$ seçilen süreçlerin şimdiki durumuna ait bir süreç yetkinlik değerlendirmesi yapılması ile sağlanır. (ISACA., 2012a, s. 20)

COBIT-5 kurumsal hedefleri BT-bağıntılı hedeflere ve onları da ilgili BT süreçlerine bağlayan eşleştirmesini kullanarak; ayrıca, risk senaryolarının odaklanılacak kilit süreçlerin nasıl altını çizebileceğini göz önünde bulundurarak uygulamanın ya da iyileştirme girişiminin kapsamını tanımlamaya odaklanır. Yüksek seviye tespitler, odaklanılacak öncelikli alanları belirlemede ve anlamada da faydalı olabilir. Daha sonra, mevcut durumun değerlendirmesi yapılır ve bir süreç kabiliyet değerlendirmesiyle talepler ya da eksiklikler tanımlanır. Büyük ölçekli girişimler, yaşam döngüsünün çoklu tekrarlamaları şeklinde yapılandırılmalıdır - altı ayı aşan herhangi bir girişimin uygulanmasında ivmeyi, odağı ve paydaşların ortaklığını kaybetme riskinin olduğu hesaba katılmalıdır.

$\mathrm{Bu}$ bağlamda ikinci aşamada diş çember kapsamında bir defa mevcut durumun tespit edilmesi gerekir. Program yönetimi kapsaminda problemli alanların ve bunların çözümünün doğuracağı fırsatların belirlenmesi gerekmektedir. Değişimin gerçekleştirilmesi için tesis edilmiş olan uygulama takımının oluşturulması gelmektedir. Bu uygulama programının mutlaka bir takım tarafından üstlenilmesi gerekmektedir. Sürekli geliştirme yaşam döngüsü kapsamında da mevcut durumun değişim karşısında bir değerlendirmesinin yapılması gerekmektedir. 
Kamu

\section{Sektöründe}

Süreç

Yapılandirmasina Teknik

Bir Yaklaşım:

Kalkınma

Ajansları

Üzerinde

COBIT-5 ile

Analiz ve

Modelleme

22

\section{Aşama 3: Nerede olmak istiyoruz?}

Üçüncü aşamada, iyileştirme için bir hedef seçilir ve ardından olası çözümleri belirlemek için bir fark analizi gerçekleştirilir. Bazı çözümler hızlı kazanımlar olabilirken diğerleri daha güç ve uzun vadeli görevler olabilir. Öncelik ulaşılması en kolay ve en çok faydayı sağlayabilecek girişimlere verilmelidir. Uzun vadeli görevler yönetilebilir daha küçük parçalara bölünmelidir. (ISACA., 2012a, s. 20)

Sırasıyla bir iyileştirme hedefine şekil verilmesinin ardından, açılıkları ve potansiyel çözümleri tanımlanmasında COBIT-5 kılavuzluğunu güçlendirmek için daha detaylı analizler yapılmalıdır. Bazı çözümler hızlı kazanımlar olabilirken diğerleri daha zorlayıcı ve uzun vadeli uygulamaları da gerektirebilir. Öncelik ulaşılması kolay ve en çok faydayı sağlayabilecek girişimlere verilmesi gerektiğinden sadece COBIT-5 yönetişim süreci ile ilgili uygulama girişiminde bulunulması tercih edilmişse de uygulamada bütüncül bir yaklaşımla daha sonra süreçler de dâhil edilmelidir.

$\mathrm{Bu}$ aşama kapsamında öncelikler nerede olmak istenildiğinin tespit edilmesi gerekir. COBIT-5 kabiliyet modelinde nereye ulaşılmak istenildiğinin ve uygulanacak olan süreçlerin kapsamlarının tespit edilmesi ve buna göre de SMDB tablolarının çizilmesi gerekmektedir. Bu nedenle de paydaşların ihtiyaçları ve kurumsal hedefler doğrultusunda COBIT-5 uygulamasının da yapılandırılması ve planlanması gerekmektedir. Dış çember olan program yönetimi kapsamında bir defa yol haritasının ortaya çıkarılması gerekmektedir. Hangi süreçler ve modeller ne zaman kimler tarafından nasıl uygulamaya konulacak ve bunun metodolojisi ne olacak bunların yol haritasına yansıtılması gerekir. Değişimin gerçekleştirilmesini içeren orta çember kapsamında da bu aşamada çıtılların belirlenmesi gelmektedir. Bu yol haritasına göre ne tür çıktılar meydana gelecek. Bunlara ait enformasyonun ilgili partilere bildirilmesi gerekmektedir. İ̧ çember olan sürekli geliştirme yaşam döngüsü kapsamında da hedef durumunun tanımlanması gelmektedir. Buna göre neticede nerede olunacaksa bunun tanımının yapılması gerekmektedir.

COBIT-5 yaşam döngüsünde ilk ele alınması gereken en dış çember "uygun ortamin oluşturulması" kapsamindaki "neredeyiz? ve nerede olmak istiyoruz?" sorusuna cevap verecek şekilde zorlukların kök nedenleri ile başarı faktörleri aşağıdaki şekilde analiz edilebilmektedir: 
Tablo 1. Ulaşılacak Hedeflerle İlgili Kök Nedenler ve Başarı Faktörleri

\begin{tabular}{|c|c|}
\hline Zorluklar & $\begin{array}{l}\text { İyileştirme amaçları için destek alamama ya da desteği sürdürememe BT ile } \\
\text { iş birimi arasındaki iletişim açığı }\end{array}$ \\
\hline $\begin{array}{l}\text { Kök } \\
\text { nedenler }\end{array}$ & $\begin{array}{l}\text { - Harekete geçmeye zorlayıcı nedenlerin açıç̧a söylenmemesi ya da var } \\
\text { olmaması } \\
\text { - Gerekli (parasal) yatırımın doğrulanması için gereken faydaların } \\
\text { algılanmaması } \\
\text { - Değişim nedeniyle etkinliğin ya da verimliliğin düşmesi } \\
\text { - Sponsora karşı sorumlulukların açıça tanımlanmaması ve iyileştirme } \\
\text { hedefleri için taahhüt eksikliği } \\
\text { - Stratejiden taktik ve işletim seviyelerine kadar iş birimi katılımı için uygun } \\
\text { yapılarının eksik olması } \\
\text { - Farklı hedef kitleleri ile iletişim için uygun yolların kurulamaması (basit } \\
\text { olamaması, öz ve iş diliyle olmaması, politika ve kültüre uymaması) ya da } \\
\text { onlara uygun tarzlara adapte olunmaması } \\
\text { - İyileştirmeler için olurluk incelemesinin iyi geliştirilmemiş olması ya da açık } \\
\text { olmaması } \\
\text { - Gerekli tüm seviyelerde değişim gerçekleştirilmesinin ve katkının yeterli } \\
\text { olmaması }\end{array}$ \\
\hline $\begin{array}{l}\text { Başarı } \\
\text { etkenleri }\end{array}$ & $\begin{array}{l}\text { - Üzerinde anlaşılan iyileştirilmiş KBTY değerinin geliştirilmesi } \\
\text { - Uygun yapılara sahip olunması. Örneğin, BT yönlendirme kurulu, denetleme } \\
\text { kurulu, amaçların iletiminin ve üzerinde anlaşılmasının kolaylaştırılması, } \\
\text { stratejinin durumunu görüşmek üzere toplantıların planlanması, yanlış } \\
\text { anlaşılmaların giderilmesi ve bilginin paylaşılması } \\
\text { - Verimli bir iş ilişkileri sürecinin uygulamaya konulması } \\
\text { - Daha yüksek yetkinlik seviyesine erişme ihtiyacını anlatan bir değişiklik } \\
\text { gerçekleştirme stratejisinin ve iletişim planının geliştirilmesi ve uygulanması } \\
\text { - Hedef kitlenin alt gruplarına uyarlanan bir biçimde genel terminolojinin ve } \\
\text { doğru dilin kullanılması (ilgi çekici hale getirilmesi ve görsellerin kullanılması) } \\
\text { - Başlangıç KBTY olurluk incelemesinin, riskleri açıkça belirterek açıklanacak } \\
\text { biçimde belirli iyileştirmeler için ayrıntılı bir olurluk incelemesi halinde } \\
\text { geliştirilmesi. Maliyetin yanı sıra (iş terimleriyle açılanan) işe katılan değere } \\
\text { de odaklanılması } \\
\text { - COBIT } 5 \text { ve bu uygulama yöntemi hakkında eğitim ve öğrenim alınması }\end{array}$ \\
\hline Zorluk & İyileştirmelerin maliyetinin sağlanan yararların üstüne çıkması \\
\hline $\begin{array}{l}\text { Kök } \\
\text { nedenler }\end{array}$ & $\begin{array}{l}\text { - Verimli iyileştirmelere ve yenilikçiliğe değil yalnızca kontrollere ve } \\
\text { performans iyileştirilmelerine odaklanma eğilimi } \\
\text { - İyileştirme programının uygun olmayan biçimde aşamalı hâle getirilmesi, } \\
\text { iyileştirme faydaları ve maliyetler arasındaki açı ilişkinin engellenmesi } \\
\text { - Düşük maliyetli ve kolay çözümlerden ziyade karmaşık ve pahalı çözümlere } \\
\text { öncelik verilmesi } \\
\text { - BT bütçesinin ve işgücünün önemli bir kısmının mevcut altyapının } \\
\text { sürdürülmesine ayrılması ve bu nedenle KBTY'ye ayrılacak personel } \\
\text { zamanının ve ilgili harcamaların çok kısıtlı kalması }\end{array}$ \\
\hline
\end{tabular}

Kamu

Sektöründe

Süreç

Yapılandırma-

sina Teknik

Bir Yaklaşım:

Kalkınma

Ajansları

Üzerinde

COBIT-5 ile

Analiz ve

Modelleme 
Kamu

\section{Sektöründe}

Süreç

Yapılandirmasina Teknik

Bir Yaklaşım:

Kalkınma

Ajansları

Üzerinde

COBIT-5 ile

Analiz ve

Modelleme

\section{4}

\begin{tabular}{|c|c|}
\hline $\begin{array}{l}\text { Başarı } \\
\text { etkenleri }\end{array}$ & $\begin{array}{l}\text { - Altyapının, süreçlerin ve İK'daki alanların tanımlanması (Örneğin daha iyi } \\
\text { bir yönetişim ile verimliliği ve doğrudan tasarrufu getirecek } \\
\text { standardizasyonun yüksek olgunluk seviyesinin ve daha az olay olmasının } \\
\text { sağlanması). } \\
\text { - Önceliklerin fayda ve uygulama kolaylığına, özellikle hızlı kazanıma dayalı } \\
\text { olması. }\end{array}$ \\
\hline Zorluk & BT ile kurum arasında güvenin ve iyi ilişkilerin olmaması \\
\hline $\begin{array}{l}\text { Kök } \\
\text { nedenler }\end{array}$ & $\begin{array}{l}\text { - Projelerde zayıf biçimde tutulan BT kayıtlarından ve hizmet dağıtımından } \\
\text { kaynaklanan eski sorunlar } \\
\text { - İş sorunlarının BT kavrayışının eksikliği ya da tam tersi durumlar } \\
\text { - Kapsam ve beklentilerin uygun biçimde açklanıp yönetilememesi } \\
\text { - Kilit kararlardan kaçınılmasına neden olan iş içinde belirsiz yönetişim rolleri, } \\
\text { sorumluluklar ve mesuliyetler } \\
\text { - İyileştirme ihtiyacını gösteren destekleyici bilgi ve ölçütlerin yokluğu } \\
\text { - Hata yapıldığının gösterilmesinden çekinilmesi, değişime karşı genel direnç }\end{array}$ \\
\hline $\begin{array}{l}\text { Başarı } \\
\text { etkenleri }\end{array}$ & $\begin{array}{l}\text { - Performans hakkında açık ve şeffaf iletişimin kurumsal performans } \\
\text { bağlantılarıyla birlikte teşvik edilmesi } \\
\text { - İş arayüzlerine ve hizmet mantığına odaklanılması } \\
\text { - Olumlu çıktıların ve çıkarılan derslerin yayımlanarak güvenirliğin kurulması } \\
\text { ve sürdürülmesi } \\
\text { - Üst düzey BT yöneticisinin güven ve iyi ilişkiler tesis etmekte güvenilir ve } \\
\text { lider olduğunun garanti altına alınması } \\
\text { - İşteki yönetişim rollerinin ve sorumluluklarının resmileştirilerek karar } \\
\text { almadaki hesap verebilirliğin açığa kavuşturulması } \\
\text { - Önerilen iyileştirmeyle ilgili gerçek sorunların kanıtlarının, kaçınılması } \\
\text { gereken risklerin ve elde edilecek faydaların (iş terimleriyle) tanımlanması ve } \\
\text { paylaşılması } \\
\text { - Değişimin gerçekleştirilmesi planına odaklanılması }\end{array}$ \\
\hline
\end{tabular}

Kaynak: (ISACA., 2012a) den alınmıştır.

\section{Aşama 4: Ne yapılması gerekiyor?}

Dördüncü aşama, gerekçelendirilebilir olurluk incelemeleri tarafından desteklenen projeleri tanımlayarak ve uygulama için bir değişiklik planı geliştirilerek makul ve pratik çözümleri planlar. İyi geliştirilmiş bir olurluk incelemesi, projenin faydalarının tanımlanmasına ve devamlı izlenmesinin sağlanmasına yardımcı olacaktır. (ISACA., 2012a, s. 20)

Uygulamada süreci destekleyecek olay ve olgular tanımlanarak kullanışlı çözümleri planlanacaktır. Ayrıca, uygulama için bir değişim planı da geliştirilmeye çalışılacaktır. İyi geliştirilmiş bir örnek olay projenin faydalarının tanımlanmasını ve izlenmesini garanti altına alacaktır. 
Dördüncü aşamada öncelikle ne yapılması gerektiği sorusuna cevap verilmesi gerekmektedir. Bu kapsamda program yönetimi çemberinde programın planlanmasının yapılması gerekir. Değişim yönetimi kapsamındaki orta çemberde ise programın uygulanması için gerekli olan rollerin tanımlanmasıdır. İç çemberdeki sürekli geliştirme yaşam döngüsü kapsamında da iyileştirmeleri yapılandırmak gerekmektedir. Ne tür iyileştirmeler yapılacağının tespit edilerek uygulamaya hazırlanması önem arz etmektedir.

COBIT-5 yaşam döngüsünde ilk ele alınması gereken en dış çember "uygun ortamın oluşturulması" kapsamındaki "Ne Yapılması Gerekiyor?" sorusuna cevap verecek şekilde zorlukların kök nedenleri ile başarı faktörleri aşağıdaki şekilde analiz edilebilmektedir:

Tablo 2. Yapılması Gereken Hususlarda Kök Nedenler ve Başarı

\section{Faktörleri}

\begin{tabular}{|c|c|}
\hline Zorluk & Çevrenin anlaşılmaması \\
\hline $\begin{array}{l}\text { Kök } \\
\text { nedenler }\end{array}$ & $\begin{array}{l}\text { - Kültür değişiklikleri, paydaş katılımı ve gerekli organizasyon } \\
\text { değişikliklerinin yeterince değerlendirilmemesi } \\
\text { - Mevcut yönetişimin gücü ile BT ve geniş yelpazede kurum içindeki } \\
\text { pratiklerinin yeterince değerlendirilmemesi }\end{array}$ \\
\hline $\begin{array}{l}\text { Başarı } \\
\text { etkenleri }\end{array}$ & $\begin{array}{l}\text { - Paydaş değerlendirmesinin yapılması ve değişim gerçekleştirme planını } \\
\text { geliştirmeye odaklanılması } \\
\text { - Mevcut güçlü noktalar ve iyi uygulamaların BT ve geniş yelpazede kurum } \\
\text { içinde yapılandırılması ve bunların kullanılması. Sadece BT için “tekerleğin } \\
\text { yeniden icadı"ndan kaçınılması } \\
\text { - Farklı destek gruplarının, bunların amaçlarının ve zihniyetlerinin anlaşılması }\end{array}$ \\
\hline Zorluk & Farklı seviyelerde karmaşıklık (teknik, organizasyonel, işletme modeli) \\
\hline $\begin{array}{l}\text { Kök } \\
\text { nedenler }\end{array}$ & $\begin{array}{l}\text { - KBTY uygulamaların az anlaşılması } \\
\text { - Tek seferde çok fazla şeyin uygulanmaya çalışılması } \\
\text { - Yetersiz uygulama deneyimiyle kritik ve zor iyileştirmelere öncelik verilmesi } \\
\text { - Karmaşı ve/veya çoklu işletme modelleri }\end{array}$ \\
\hline $\begin{array}{l}\text { Başarı } \\
\text { etkenleri }\end{array}$ & $\begin{array}{l}\text { - COBIT } 5 \text { ve bu uygulama yöntemi hakkında eğitim ve öğrenim alınması } \\
\text { - Daha küçük projelere bölmek, bir seferde bir adım yapılandırmak, hızlı } \\
\text { kazanımlara öncelik vermek } \\
\text { - Farklı müşterilerin iyileştirme ihtiyaçlarının toplanması, bunların bağlantıları } \\
\text { ile öncelik sıralarının belirlenmesi ve değişiklik gerçekleştirme programıyla } \\
\text { eşleştirilmesi } \\
\text { - Uygulamanın aşamalı hale getirilmesi için iş önceliklerine odaklanılması }\end{array}$ \\
\hline Zorluk & $\begin{array}{l}\text { COBIT 5, ilgili çerçeveler, prosedürler ve uygulamaların anlaşılmasında } \\
\text { güçlülk çekilmesi }\end{array}$ \\
\hline Kök & - Yetersiz beceri ve bilgi birikimi \\
\hline
\end{tabular}

Kamu

Sektöründe

Süreç

Yapılandırma-

sina Teknik

Bir Yaklaşım:

Kalkınma

Ajansları

Üzerinde

COBIT-5 ile

Analiz ve

Modelleme 
Kamu

\section{Sektöründe}

Süreç

Yapilandirmasina Teknik

Bir Yaklaşım:

Kalkınma

Ajansları

Üzerinde

COBIT-5 ile

Analiz ve

Modelleme

26

\begin{tabular}{|c|c|}
\hline nedenler & $\begin{array}{l}\text { - İyi uygulamaların uyarlanması yerine bire bir kopyalanması } \\
\text { - Roller, sorumluluklar ve uygulanan beceriler gibi diğer etkinleştiriciler yerine } \\
\text { sadece prosedürlere odaklanılması }\end{array}$ \\
\hline leri & $\begin{array}{l}\text { - COBIT 5, diğer standartlar ve iyi uygulamalar ile COBIT } 5 \text { uygulama } \\
\text { yöntemi hakkında eğitim ve öğrenim alınması } \\
\text { - Gerekirse, nitelikli ve deneyimli dış rehberlik ve destek alınması } \\
\text { - İyi uygulamaların kurumsal çevreye adapte edilmesi } \\
\text { - Süreçlerin tasarımı sırasında gerekli beceriler, roller, sorumluluklar, süreç } \\
\text { sahiplikleri, amaçlar ve hedeflerin değerlendirilmesi ve bunlarla ilgilenilmesi }\end{array}$ \\
\hline Zorluk & eğişime direnilmesi \\
\hline $\begin{array}{l}\text { Kök } \\
\text { nedenler }\end{array}$ & $\begin{array}{l}\text { Statüko tehdit edildiğinde direnmek doğal bir davranıştır ama bu aşağıdakiler } \\
\text { gibi altta yatan başka kaygıları işaret edebilir: } \\
\text { - Neyin gerekli olduğunun ve bunun neden kullanışlı olduğunun yanlış } \\
\text { anlaşılması } \\
\text { - İş yükünün ve maliyetin artacağı anlayışı } \\
\text { - Noksanlıkların varlığını kabul etmekte gönülsüzlük } \\
\text { - Kurumda genelleyici yönetişim çerçevelerinin zorlanmasının güçlendirdiği } \\
\text { "burada icat edilmedi” sendromu } \\
\text { - Kemikleşmiş rol ya da güç temeline tehdit }\end{array}$ \\
\hline $\begin{array}{l}\text { Başarı } \\
\text { etkenleri }\end{array}$ & $\begin{array}{l}\text { - Farkındalık iletişiminin belirli sorunlu noktalara ve itici etkenlere } \\
\text { odaklanması } \\
\text { - İş ve BT yöneticileri ile paydaşların eğitilmesiyle farkındalığın artırılması } \\
\text { - İş ve BT becerileri olan deneyimli bir değişim temsilcisinin kullanılması } \\
\text { - İlgili taraflarda uygulama faydalarının gerçekleştirildiğinden emin olmak } \\
\text { için düzenli kilometre taşlarının takip edilmesi } \\
\text { - Hızlı kazanımlara ve kolay elde edilebilir dikkat çekici şeylere gidilerek } \\
\text { aydınlatıcı durumların sağlanması } \\
\text { - COBIT } 5 \text { gibi genel çerçevelerin kurumun kapsamına uygun hâle getirilmesi } \\
\text { - Aşağıdakiler gibi değişiklik gerçekleştirme planlanmasına odaklanılması: } \\
\text { - Geliştirme } \\
\text { - Eğitim } \\
\text { - Eğitmenlik } \\
\text { - Akıl hocalığı } \\
\text { - Beceri aktarımı } \\
\text { - Faydaları teşvik etmek için gösteriler düzenlenmesi ve şampiyonlar } \\
\text { bulunması }\end{array}$ \\
\hline Zorluk & İyileştirmelere uyumun başarısız olması \\
\hline $\begin{array}{l}\text { Kök } \\
\text { nedenler }\end{array}$ & $\begin{array}{l}\text { - Diş uzmanların çözümleri izole biçimde tasarlaması ya da yeterli açıklamada } \\
\text { bulunmadan çözümleri dikte etmeleri } \\
\text { - İç KBTY takımının izole çalışması ve gerçek süreç sahiplerinin yerine hareket } \\
\text { ederek yanlış anlaşılmalara ve değişime direnilmesine neden olmaları } \\
\text { - Kilit paydaşların yetersiz destek vermesi ve yönlendirmesi, dolayısıla KBTY } \\
\text { projelerinin gerçek sahipleri olmayan yeni politikalar ve prosedürler üretmesi }\end{array}$ \\
\hline Başarı & lerinin ve diğer paydaşların tasarım sırasında çalışmalara dâhil \\
\hline
\end{tabular}




\begin{tabular}{|c|c|}
\hline etkenleri & $\begin{array}{l}\text { edilmesi } \\
\text { - Eğitim için ortaklık sağlayacak desteğin elde edilmesi için uygun örnek } \\
\text { çalışmalar ve tanıtıcı gösterimler kullanılması } \\
\text { - Hızlı kazanımlarla başlanması, faydaların gösterilmesi ve işin temelinin } \\
\text { buradan kurulması } \\
\text { - Gelişmek isteyen şampiyonların bulunması, buradan elde edilen faydaların } \\
\text { ve yapılanmanın gösterilmesi } \\
\text { - Direnen insanları zorla seçmektense iyileştirmeyi isteyen şampiyonların } \\
\text { bulunması } \\
\text { - Rolleri ve sorumlulukları kendisi atayan, sürekli işletime bağlı olan ve } \\
\text { uyumu izleyen bir yönetimin özendirilmesi } \\
\text { - Dış uzmanlardan süreç sahiplerine bilgi birikimi aktarımının zorlanması } \\
\text { - Sorumluluğun dağıtılması ve süreç sahiplerinin güçlendirilmesi }\end{array}$ \\
\hline Zorluk & $\begin{array}{l}\text { İç yönetişim yaklaşımının dış kaynak paydaşlarının yönetişim modelleri ile } \\
\text { bütünleştirilmesinde zorluk yaşanması }\end{array}$ \\
\hline $\begin{array}{l}\text { Kök } \\
\text { nedenler }\end{array}$ & $\begin{array}{l}\text { - Uygun olmayan uygulamaların ortaya çıkması korkusu } \\
\text { - KBTY gereksinimlerinin dış kaynak sağlayıcılarla paylaşılamaması ve/veya } \\
\text { onlara özel tanımlanamaması } \\
\text { - Belirli olmayan rol ve sorumluluk paylaşımı } \\
\text { - Yaklaşım ve beklentilerdeki farklılıklar }\end{array}$ \\
\hline $\begin{array}{l}\text { Başarı } \\
\text { etkenleri }\end{array}$ & $\begin{array}{l}\text { - Tedarikçilerin/üçüncü tarafların uygun yerlerde uygulamaya ve işletim } \\
\text { faaliyetlerine dâhil edilmesi } \\
\text { - Katılım şartlarına ve denetleme haklarına sözleşmelerde yer verilmesi } \\
\text { - Çerçevelerin ve yaklaşımların bütünleştirilmesi için yollar aranması } \\
\text { - Rollerin, sorumlulukların ve yönetişim yapılarının üçüncü taraflara önceden } \\
\text { belirtilmesi, sonradan verilmemesi } \\
\text { - Hizmet sağlayıcı süreçlerinin, kişilerinin ve teknolojilerinin kanıtlarının } \\
\text { (denetim ve belge gözden geçirme yoluyla) gerekli KBTY uygulamaları ve } \\
\text { seviyeleriyle eşleştirilmesi }\end{array}$ \\
\hline
\end{tabular}

Kaynak: (ISACA., 2012a) den alınmıştır.

\section{Aşama 5: Oraya nasıl gideriz?}

Beşinci aşamada, iş hizalanmasının başarılmasını ve performansının ölçülebilmesini garanti altına almak için önerilen çözümlerin gündelik pratiklere dökülmesini ve ölçütler ile izleme mekanizmalarının kurulması sağlanır. Başarı; işe dahil olmayı, farkındalık ve iletişimi, üst yönetimin taahhüdünü ve işi anlamasını, ve etkilenen iş birimi ile BT süreç sahiplerinin sahipliğini gerektirir. (ISACA., 2012a, s. 20)

$\mathrm{Bu}$ aşamada, önerilen çözümler günlük etkinliklerin içinde yürürlüğe geçirilir. Ölçümler tanımlanabilir ve izleme mekanizması kurulur; COBIT-5 hedefleri ve metrikleri kullanılarak iş hizalanmasına 
Kamu

\section{Sektöründe}

Süreç

Yapilandirmasina Teknik

Bir Yaklaşım:

Kalkınma

Ajansları

Üzerinde

COBIT-5 ile

Analiz ve

Modelleme

28 erişildiği ve sürdürüldüğ̈̈ garanti altına alınır, performans ölçülebilir. Başarıya ulaşmak için üst yönetimin taahhüdü ve bağl1lığının gösterilmesi kadar etkilenen iş ve BT paydaşlarının sahiplenmesi de gereklidir. Bu sahiplenmenin sağlanması durumunda uygulamanın kolay bir şekilde gerçekleştirilmesi sağlanacaktır.

Beşinci aşamada nasıl gidileceği sorusuna öncelikle cevap verilmesi gerekir. Yöntem ve metodoloji ile araçların belirlenmesini gerektirmektedir. Çünkü program yönetimi alanında öncelikle planın uygulanması, değişim gerçekleştirme kapsamında işletme ve kullanma ve sürekli geliştirme yaşam döngüsü kapsamında da iyileştirmelerin uygulanması bu aşamada yapılması gerekenlerdir. COBIT-5 yaşam döngüsünde ilk ele alınması gereken en dış çember "uygun ortamın oluşturulması" kapsamindaki "Oraya Nasıl Gideriz?" sorusuna cevap verecek şekilde zorlukların kök nedenleri ile başarı faktörleri aşağıdaki şekilde analiz edilebilmektedir:

\section{Tablo 3. Oraya Nasıl Gideriz?'e Verilecek Cevabı Belirleyen} Zorluklardaki Kök Nedenler ve Başarı Faktörleri

\begin{tabular}{|c|c|}
\hline Zorluk & Uygulama taahhütlerinin gerçekleştirilmesinde başarısızlık \\
\hline $\begin{array}{l}\text { Kök } \\
\text { nedenler }\end{array}$ & $\begin{array}{l}\text { - Fazla iyimser amaçlar, harcanacak çabanın küçümsenmesi } \\
\text { - BT'nin yangın söndürme hâlinde olması ve işletimsel sorunlara odaklanması } \\
\text { - Adanmış kaynakların ya da kapasitenin yokluğu } \\
\text { - Önceliklerin yanlış saptanması } \\
\text { - Kapsamın gereksinimlerle uyumlu olmaması ya da uygulayıcılar tarafından } \\
\text { yanlış yorumlanması } \\
\text { - Olurluk incelemesi gibi program yönetimi ilkelerinin iyi uygulanmaması } \\
\text { - İș çevrelerine, örneğin işletme modeline dair yetersiz kavrayıș }\end{array}$ \\
\hline $\begin{array}{l}\text { Başarı } \\
\text { etkenleri }\end{array}$ & $\begin{array}{l}\text { - Beklentilerin yönetilmesi } \\
\text { - Rehberlik ilkelerinin izlenmesi } \\
\text { - Uygulamanın basit, gerçekçi ve pratik tutulması } \\
\text { - Tüm projenin, daha küçük ve ulaşılabilir kazanımlı projelere bölünmesi, } \\
\text { böylece deneyim ve fayda kazanılması } \\
\text { - Uygulama kapsamının gereksinimleri desteklediğinden emin olunması ve } \\
\text { tüm paydaşların kapsamın sunacağı çıktılardan aynı şeyi anlamaları } \\
\text { - İş değeri sağlayacak uygulamalara odaklanılması } \\
\text { - Adanmış kaynakların ayrıldığına emin olunması } \\
\text { - Program yönetimi ve yönetişim ilkelerinin uygulanması } \\
\text { - Mevcut mekanizmaların ve çalışma biçimlerinin desteklenmesi } \\
\text { - İş çevresine dair uygun kavrayışın sağlanması }\end{array}$ \\
\hline Zorluk & $\begin{array}{l}\text { Tek seferde çok şey yapmanın denenmesi; fazlasıyla karmaşık ve/veya zor } \\
\text { problemlerle mücadele edilmesi }\end{array}$ \\
\hline $\begin{array}{l}\text { Kök } \\
\text { nedenler }\end{array}$ & $\begin{array}{l}\text { - Kapsamın ve harcanacak çabanın (insan boyutu, ortak dilin yaratılması } \\
\text { dahil) anlaşılmaması }\end{array}$ \\
\hline
\end{tabular}




\begin{tabular}{|c|c|}
\hline & $\begin{array}{l}\text { - Değişimi özümseme kapasitesinin anlaşılmaması (çok fazla girişim) } \\
\text { - Resmi program planlaması ve yönetiminin olmaması; bir temel } \\
\text { oluşturulmaması ve bu temeldeki çabanın olgunlaştırılmaması } \\
\text { - Uygulamaya başlanılması için gereksiz baskı } \\
\text { - Hızlı kazanımlardan yararlanılmaması } \\
\text { - Tekerleğin baştan icat edilmesi ve var olanın bir temel olarak kullanılmaması } \\
\text { - Organizasyonel yapıyla ilgili kavrayışın yokluğu } \\
\text { - Becerilerin eksikliği }\end{array}$ \\
\hline $\begin{array}{l}\text { Başarı } \\
\text { etkenleri }\end{array}$ & $\begin{array}{l}\text { - Program ve proje yönetim ilkelerinin uygulanması } \\
\text { - Kilometre taşlarının kullanılması } \\
\text { - Görevlere 80/20 öncelik verilmesi (yüzde } 20 \text { çaba ile faydanın yüzde } 80^{\prime} \text { nini } \\
\text { elde etme) ve doğru sırada dizilmeleri konusunda özen gösterilmesi. Hızlı } \\
\text { kazanımlardan yararlanılması } \\
\text { - Güven/güvenilirlik oluşturulması. Uygulamanın basit ve pratik tutulması } \\
\text { için gerekli becerilere ve deneyime sahip olunması } \\
\text { - Mevcut şeylerin bir temel olarak yeniden kullanılması }\end{array}$ \\
\hline Zorluk & $\begin{array}{l}\text { BT ve/veya iş birimlerinin yangın söndürme hâlinde olması, öncelik } \\
\text { sıralamasını düzgün yapamamaları ve yönetişime odaklanamamaları }\end{array}$ \\
\hline $\begin{array}{l}\text { Kök } \\
\text { nedenler }\end{array}$ & $\begin{array}{l}\text { - Kaynak ya da beceri eksiklikleri } \\
\text { - İç süreçlerin yokluğu, iç verimsizlikler } \\
\text { - Güçlü BT liderliğinin yokluğu } \\
\text { - Çok fazla geçici çözümün olması }\end{array}$ \\
\hline $\begin{array}{l}\text { Başarı } \\
\text { etkenleri }\end{array}$ & $\begin{array}{l}\text { - İyi liderlik becerilerinin uygulanması } \\
\text { - Üst yönetimin bağlılığı ve yürütmesiyle insanların KBTY'ye odaklanmasına } \\
\text { uygun hâle getirilmesi } \\
\text { - İşletme çevresindeki kök nedenlere seslenilmesi (dış müdahale, yönetimin } \\
\text { BT'ye öncelik vermesi) } \\
\text { - İş taleplerinin yönetiminin daha sıkı disiplin altına alınması } \\
\text { - Uygun olan yerlerde dış kaynakların kullanılması } \\
\text { - Dış yardım elde edilmesi }\end{array}$ \\
\hline Zorluk & $\begin{array}{l}\text { Gerekli beceri ve yetkinlik eksikliği, örneğin, yönetişimin anlaşılması, } \\
\text { yönetim, iş, süreçler, kişisel yetenekler }\end{array}$ \\
\hline $\begin{array}{l}\text { Kök } \\
\text { nedenler }\end{array}$ & $\begin{array}{l}\text { - COBIT ve BT yönetimi iyi uygulamalarının yeterince anlaşılmaması } \\
\text { - Eğitimde sıklıkla iş ve yönetim becerilerine yer verilmemesi } \\
\text { - BT çalışanlarının teknik olmayan alanlarla ilgilenmemesi } \\
\text { - İş birimi çalışanlarının BT ile ilgilenmemesi }\end{array}$ \\
\hline $\begin{array}{l}\text { Başarı } \\
\text { etkenleri }\end{array}$ & $\begin{array}{l}\text { - Değişiklik gerçekleştirme planlamasına odaklanılması: } \\
\text { - Geliştirme } \\
\text { - Eğitim } \\
\text { - Eğitmenlik } \\
\text { - Akıl hocalığı } \\
\text { - İşe alım sürecine geri bildirim } \\
\text { - Çapraz beceri eğitimi }\end{array}$ \\
\hline
\end{tabular}

Kamu

Sektöründe

Süreç

Yapılandirma-

sina Teknik

Bir Yaklaşım:

Kalkınma

Ajansları

Üzerinde

COBIT-5 ile

Analiz ve

Modelleme

Kaynak: (ISACA., 2012a) den alınmıştır. 
Kamu

\section{Sektöründe}

Süreç

Yapılandirmasina Teknik

Bir Yaklaşım:

Kalkınma

Ajansları

Üzerinde

COBIT-5 ile

Analiz ve

Modelleme

30

\section{Aşama 6: Ulaştık mı?}

Altıncı aşama, iyileştirilmiş yönetişim ve yönetim pratiklerinin normal iş faaliyetlerine sürdürülebilir bir şekilde dönüşümüne ve performans ölçütleri ve beklenen faydaları kullanarak iyileştirme başarısının izlenmesine odaklanır. (ISACA., 2012a, s. 20) Yeni ya da iyileştirilmiş geliştiricilerin sürdürülebilir işletimi ile beklenen faydalara ulaşılmasının izlenmesine odaklanır. "Ulaştık mı?" sorusuna cevap aranılan bu aşamada durum değerlendirmesi yapılmasına ihtiyaç duyulmaktadır. Program yönetimi kapsamında kamu yararının veya katma değerin gerçekleştirilmesi gelmektedir. Değişim yönetimi kapsamında yeni yaklaşım ve medolojilerin sürece dahil edilmesi, sürekli geliştirme yaşam döngüsü kapsamında da işletim ve ölçmenin devam ettirilmesi öngörülmektedir.

\section{Aşama 7: Devinimi nasıl koruruz?}

Yedinci aşama, girişimin genel başarısını gözden geçirir, yönetişim ve yönetim gereksinimlerini tanımlar, sürekli iyileştirme ihtiyacını güçlendirir. Ayrıca, KBTY'yi iyileştirmek için başka fırsatları da önceliklendirir. (ISACA., 2012a, s. 20)

Program ve proje yönetimi, iyi uygulamaları baz almaktadır ve yedi aşamanın her biri için kontrol noktası sağlar. Böylece program performansının beklenene uygun olduğu, olurluk incelemesinin ve risklerinin güncel olduğu, bir sonraki aşamaya ait planlamanın uygun biçimde ayarlanmış olduğu garanti altına alınır. Kurumun standart yaklaşımının izleneceği varsayılır. Program ve proje yönetimine dair daha fazla rehberlik, COBIT 5'in BAI01 sürecinde bulunabilir. Aşamaların herhangi birisinde raporlama açıkça belirtilmemiş olsa da, tüm aşamalarda ve tekrarlamalarda süregiden bir iştir. (ISACA., 2012a, s. 20)

Her aşama için harcanan süre (başka faktörlerin yanı sıra) kurumun özel ortamına, yetkinliğine ve girişimin uygulama ya da iyileştirme kapsamına göre büyük farklılık gösterecektir. Ancak, ideal olarak tüm bir yaşam döngüsünün tekrarlanması için harcanan toplam süre altı ayı geçmemelidir ve iyileştirmeler ilerledikçe uygulanmalıdır. Aksi takdirde ivme, odak ve paydaşların desteğini kaybetmenin riski vardır. Amaç düzenli bir iyileştirme ritmi yakalamaktır. Büyük ölçekli girişimler, yaşam döngüsünün çoklu tekrarları şeklinde yapılandırılmalıdır. (ISACA., 2012a, s. 20) Zamanla, sürdürülebilir bir yaklaşım yapılandırılırken bir yandan da yaşam döngüsü tekrarlı bir şekilde takip edilecektir. Yaşam döngüsünün aşamaları günlük olağan faaliyetlerine dönüştüğünde bunlar normal iş 
uygulaması haline gelir ve sürekli iyileştirme doğal biçimde oluşur. (ISACA., 2012a, s. 20)

Bu son aşama sırasında, öncelikle hızlanmanın nasıl sürdürüleceği sorusuna cevap verilmesi gerekmektedir. Program yönetimi kapsamında COBIT-5 uygulama girişiminin toplam başarısı ve etkililiği gözden geçirilir, kuruluş BT'sinin yönetişimi ya da yönetimi için gerekli ileriki gereksinimler tanımlanır, sürekli iyileştirme ihtiyacı güçlendirilir. Değişim yönetim yönetimi kapsamında uygulamanın sürdürülmesi ve sürekli geliştirme yaşam döngüsü kapsamında da izleme ve değerlendirme faaliyetlerine devam edilmesi öngörülmektedir. COBIT-5 yaşam döngüsünde ilk ele alınması gereken en diş çember "uygun ortamın oluşturulması" kapsamındaki "Ulaştık mı? ve Devinimi nasıl koruruz?" sorusuna cevap verecek şekilde zorlukların kök nedenleri ile başarı faktörleri aşağıdaki şekilde analiz edilebilmektedir:

Kamu

Sektöründe

Süreç

Yapılandirma-

sina Teknik

Bir Yaklaşım:

Kalkınma

Ajansları

Üzerinde

COBIT-5 ile

Analiz ve

Modelleme

Tablo 4. Ulaştık mı? Sorusuna Verilecek Cevabı Belirleyen Zorluklardaki Kök Nedenler ve Başarı Faktörleri

\begin{tabular}{|c|c|}
\hline Zorluk & ileştirmelerin benimsenmemesi ya da uygulanmaması \\
\hline $\begin{array}{l}\text { Kök } \\
\text { nedenler }\end{array}$ & $\begin{array}{l}\text { - Çözümlerin çok karmaşık ya da kullanışsız olması } \\
\text { - Çözümlerin danışmanlar ya da uzman takım tarafından izole biçimde } \\
\text { geliştirilmesi } \\
\text { - İyi uygulamaların kopyalanması ama kurum işleyişine göre } \\
\text { uyarlanmaması • Çözümlerin süreç sahipleri/takımı tarafından } \\
\text { "sahiplenilmemesi” } \\
\text { - Organizasyonun açık rollere ve sorumluluklara sahip olmaması } \\
\text { - Yönetimin değişimi zorlayıp desteklememesi } \\
\text { - Değişime direnilmesi } \\
\text { - Yeni süreçlerin ya dageliştirilen araçların nasıl uygulanacağının yeterince } \\
\text { kavranamaması } \\
\text { - Rol gereksinimleriyle becerilerin ve profilin uymaması }\end{array}$ \\
\hline $\begin{array}{l}\text { Başarı } \\
\text { etkenler }\end{array}$ & $\begin{array}{l}\text { - Hızlı kazanımlara ve yönetilebilir projelere odaklanılması } \\
\text { - Yaklaşımın test edilmesi ve çalıştığına emin olmak için küçük iyileştirmeler } \\
\text { yapılması } \\
\text { - İyileştirmeler geliştirilirken süreç sahipleri ve diğer paydaşların dâhil } \\
\text { edilmesi } \\
\text { - Rollerin ve sorumlulukların açık ve kabul edilir olmasının sağlanması, gerek } \\
\text { görülürse rollerin ve iş tanımlarının değiştirilmesi } \\
\text { - Iyileştirmelerin kurumda yönetimden başlayarak aşağıya doğru } \\
\text { sürdürülmesi } \\
\text { - Gerekli yerlerde uygun eğitimin sağlanması } \\
\text { - Otomatikleştirmeden önce süreçlerin geliştirilmesi } \\
\text { - Gerek görülürse süreç sahipliğinin daha iyi olması için yeniden düzenleme } \\
\text { yapılması } \\
\text { - Roller (özellikle başarılı benimsenme için kilit olanlar) ile bireysel }\end{array}$ \\
\hline
\end{tabular}


Kamu

Sektöründe

Süreç

Yapılandirmasina Teknik

Bir Yaklaşım:

Kalkınma

Ajansları

Üzerinde

COBIT-5 ile

Analiz ve

Modelleme

32

\begin{tabular}{|c|c|}
\hline & $\begin{array}{l}\text { yetkinlikler ve özelliklerin eşleştirilmesi } \\
\text { • Verimli eğitim ve öğretim sağlanması }\end{array}$ \\
\hline Zorluk & Faydaların gösterilmesi ya da ispatlanmasındaki zorluk \\
\hline $\begin{array}{l}\text { Kök } \\
\text { nedenler }\end{array}$ & $\begin{array}{l}\text { - Amaçlar ve ölçütlerin kurulmaması ya da verimli çalışmaması } \\
\text { - Uygulamadan sonra faydaların takibinin yapılmaması } \\
\text { - Kazanılacak fayda ve değerlere odaklanmanın kaybedilmesi • } \\
\text { Başarının yeterince paylaşılmaması }\end{array}$ \\
\hline $\begin{array}{l}\text { Başarı } \\
\text { etkenleri }\end{array}$ & $\begin{array}{l}\text { - Açı, ölçülebilir ve gerçekçi amaçlar konulması (iyileştirmeden çıtı } \\
\text { beklenir) } \\
\text { - Uygulanabilir performans ölçütlerinin konulması (iyileştirmenin } \\
\text { amaçlara ulaşmaya katkısının izlenmesi için) } \\
\text { - Performansın nasıl ölçüldüğünü gösteren puan çizelgeleri üretilmesi } \\
\text { - Elde edilen sonuçların ve faydaların iş etkisi terimleri cinsinden } \\
\text { paylaşımı } \\
\text { - Hızlı kazanımların uygulanması ve çözümlerin kısa sürelerde } \\
\text { sağlanması }\end{array}$ \\
\hline Zorluk & İlginin ve ivmenin kaybolması \\
\hline $\begin{array}{l}\text { Kök } \\
\text { nedenler }\end{array}$ & $\begin{array}{l}\text { - Sürekli iyileştirmenin kültürün bir parçası olmaması } \\
\text { - Yönetimin sürdürülebilir sonuçlara sevk etmemesi } \\
\text { - Kaynakların iyileştirme yerine yangın söndürme ve hizmet } \\
\text { dağıtımına odaklanması } \\
\text { - Çalışanların motive olmaması, değişimin benimsenmesi ve } \\
\text { yürütülmesinde kişisel fayda görememeleri }\end{array}$ \\
\hline $\begin{array}{l}\text { Başarı } \\
\text { etkenleri }\end{array}$ & $\begin{array}{l}\text { - Yönetimin sağlam ve güvenilir hizmet, çözüm ve iyi yönetişim } \\
\text { ihtiyaçlarını düzenli olarak paylaştığının garanti altına alınması. } \\
\text { Hâlihazırda ulaşılmış olan başarılı iyileştirmelerin tüm paydaşlarla } \\
\text { paylaşılmasının sağlanması } \\
\text { • Paydaşların yeniden ziyaret edilmesi ve ivmeyi "gazlamak" için } \\
\text { desteklerinin alınması } \\
\text { • Eğer kaynaklar kıtsa iyileştirme uygulamalarının günlük iş } \\
\text { hayatında "iş üzerinde" yapılması şansının kullanılması } \\
\text { • Düzenli ve yönetilebilir iyileştirme görevlerine odaklanılması } \\
\text { - Bir yandan dıs yardım sağlanırken bir yandan da bağlantılı } \\
\text { kalınması } \\
\text { - Süreçlerin, organizasyon performans iyileştirme hedeflerinin ve } \\
\text { ölçütlerin kişisel ödül sistemleriyle hizalanması }\end{array}$ \\
\hline
\end{tabular}

Kaynak: (ISACA., 2012a) den alınmıştır. 


\section{4.İyi Uygulamalar}

COBIT-5, gerçekleştirici süreçleri, süreç içi iyi uygulamaların artan detay seviyeleriyle açıklandığı bir süreç referans modeli içerir. Bunlar; uygulamalar, faaliyetler ve detaylı faaliyetler şeklinde ifade edilebilir. İyi uygulamaların KB tarafından diğer KA uygulamaları için önerilmesi ve bu alanda koordinasyonlu çalışılması önem arz etmektedir. ANKA'nda pek çok göreve ait tanımlama ve ilgili oldukları süreçlerin work-flow denilen haritaları çıkarılmıştır. İş tanımları ile süreçlerin bu kapsamda ayrı ayrı inceleme konusu edilmesi gerekmektedir.

\section{Uygulamalar}

Yönetişim/yönetim uygulamaları, her COBIT-5 süreci için, kalkınma ajansının BT'sinin etkili ve pratik yönetişim ve yönetimi için yüksek seviyedeki koşulların tam bir takımını sağlar. Bu uygulamalar, kurumsal faydaların sağlanması, risk seviyesinin optimizasyonu ve kaynak kullanımının optimizasyonu için yapılacak uygulamalar olup, iyi uygulamalar ve yaygın olarak kabul görmüş standartlara uygun olacak şekilde hizalanır. Aynı zamanda bu uygulamalar, genel kapsamlıdır ve dolayısıyla her kalkınma ajansının için uyarlanması mümkündür.

KA yönetim kurulu ve yönetim, bu yönetişim ve yönetim uygulamaları ile ilgili tercihleri aşağıdaki şekilde yapmalıdır:

a) Uygulanabilecek olanları seçmeli ve uygulanacak olanlar üzerinde karar vermeli,

b) Gerekli olduğunda uygulamaları eklemeli ve/veya uyarlamalı,

c) İş süreçlerinde entegrasyon için BT-bağlantılı olmayan uygulamaları tanımlamalı ve eklemeli,

d) Bunların nasıl uygulanacağını seçmeli (sıklık, süre, otomasyon vb.),

e) Uygulanabilecek olanların uygulanmama riskini kabul etmeli.

\section{Faaliyetler}

COBIT-5 dâhilinde süreci yürütmek için yapılan ana eylemlere faaliyet denir. Faaliyetler; "KA kurumsal hedeflerinin, BT'sinin ve iş süreçlerinin başarılı yönetişim ve yönetimi için yönetim uygulamaların gerçekleştirme kılavuzu" olarak tanımlanır. COBIT-5 faaliyetleri, BT performansını geliştirmek ve/veya BT çözümünü ve hizmet teslim riskini ele alacak şekilde her yönetişim veya yönetim uygulaması için neyin, neden ve nasıl uygulanacağını öngörür. (ISACA, COBIT 5: A Business
Kamu

Sektöründe

Süreç

Yapılandırma-

sina Teknik

Bir Yaklaşım:

Kalkınma

Ajansları

Üzerinde

COBIT-5 ile

Analiz ve

Modelleme 
Kamu

Sektöründe

Süreç

Yapılandirmasina Teknik

Bir Yaklaşım:

Kalkınma

Ajansları

Üzerinde

COBIT-5 ile

Analiz ve

Modelleme

34
Framework for the Governance and Management of Enterprise IT., 2012) Bu boyut aşağıdaki yararları sağlamaktadır:

a) KA kritik iş süreçleri ile BT'sini planlaması, oluşturması, çalıştırması veya izlemesi (PBRM) gereken yönetim, hizmet sağlayıcıları, son kullanicilar ve BT profesyonelleri

b) Güncel veya öngörülen uygulamalar veya gerekli geliştirmelerle ilgili olarak fikirleri sorulabilecek güvence profesyonelleri

c) Ana yönetişim uygulaması (YU), yönetim müdüriyet uygulamasını (MU) gerçekleştirmek için gerekli ve yeterli olan tüm aşamaları içeren bir yaklaşım sağlayan genel ve özel faaliyetlerin tam bir takımı.

Bunlar, fiili performansın değerlendirilmesi ve potansiyel geliştirmelerin dikkate alması için YU/MU için yüksek seviyede rehberlik sağlar. Bu faaliyetler:

-YU/MU gerçekleştirmek için gerekli ve yeterli olan bir takım eylem odaklı uygulama aşamaların açıklar.

-Sürecin girdi ve çıktılarını göz önünde bulundurur

-İyi uygulamalar ve yaygın olarak kabul görmüşs standartlara dayanır

-Görev ve sorumlulukların açık bir şekilde tesis edilmesini destekler

-Kural koyucu nitelikte değildir ve KA için uygun olan özel prosedürler halinde uyarlanmalı ve geliştirilmelidir.

\section{Çalışma Ürünleri: Girdiler ve Çıktılar}

COBIT-5 girdi ve çıktıları, sürecin işleyişini desteklemek için gerekli olduğu düşünülen süreç iş ürünleri/yapılarıdır. Yönetim ve yönetişim süreçleri bir birilerine girdi temin ederler ve bu anlamda bir bütünlük arz ederler. Bunlar, önemli kararları gerçekleştirir, süreç faaliyetlerinin bir kaydını ve denetim izi sağlar ve bir olay durumunda takibi gerçekleştirir. Ana yönetişim/yönetim uygulama seviyesinde tanımlanırlar ve bunlara sadece süreç içinde kullanılan bazı iş ürünleri de dâhildir ve sıklıkla diğer süreçler açısından temel girdileri oluştururlar.

\section{SONUÇ}

Yetki devri karar verme, uygulama ve talimatlandırma ile ilgili kanuni gücün başkalarına devretmek ve bunun sonuçlarından da sorumlu tutmak şeklinde ifade edilebilir. 1050 sayılı Muhasebe-i umumiye Kanununa göre yetki sorumlulukla birlikte devredilirken 5018 sayll Mali Kontrol Kanununda mali sorumluluk devredilirken yetkiyi devredenlerin idari olarak sorumlu olmaya devam ettikleri hüküm altına alınmıştır. Bu 
anlamda yetkiyi devreden yetkinin ne şekilde kullanıldığını takip etmeli ve doğru kullanımla ilgili gerekli makul düzeyde önlemleri almalıdır. ANKA'nda yetki devri ile ilgili olarak mevzuata uygun olarak süreçlerin işletildiği görülmüştür. Örneğin Kanun tarafından YK Başkanının bir takım yetkilerini GS'e devredebileceği belirtildiğinden dolayı uygulamada pek çok konuda YK kararı ile bir takım görevler GS'e verilmektedir. Bunun dışında GS tarafından da birim başkanlarına yetki devri yapılmadığı tespit edildiğinden dolayı etkin bir süreç yönetimi için gerekli olan yetki devrinin sağlanılması önerilmiştir.

Ankara KA'nda aşağıdaki süreçlere ait haritalar (iş akışları) çıkarılmıştır:

Tablo 5. ANKA'nda Tanımlı Ana ve Alt Süreç İsimleri

\begin{tabular}{|c|c|c|c|c|c|}
\hline Sir & Biri & Sürec Adı & Sira & Biri & Sürec Adı \\
\hline & $\mathrm{DH}$ & Disiolin & 2 & PYB & DFD Deăerlendirme Süreci \\
\hline 2 & $\mathrm{DH}$ & Doğrudan temin & & PYB & DFD Rehber Hazırlanması \\
\hline & $\mathrm{DH}$ & Eğitim & & PYB & DFD Sözlesme ve Uvqulama \\
\hline & $\mathrm{DH}$ & Gelir Toplanması & 2 & PYB & MDP Ana Sürecler \\
\hline & $\mathrm{DH}$ & Hastalık İzni & 2 & PYB & MDP Basvuru Kabul Süreci \\
\hline & $\mathrm{DH}$ & İhale & & PYB & $\mathrm{MDP} \quad \mathrm{BD}$ Değerlendirme \\
\hline & $\mathrm{DH}$ & İse Alım & & PYB & MDP BD Secilmesi \\
\hline & $\mathrm{DH}$ & İsten Avrulma & 3 & PYB & Bilgilendirme \\
\hline & $\mathrm{DH}$ & Proie Nakit Teminat & & PYB & MDP Destek Eğitim Süreci \\
\hline & $\mathrm{DH}$ & Proie Nakit Teminat & & PYB & MDP DK Secilmesi \\
\hline & $\mathrm{DH}$ & Teminat & & PYB & MDP DK ve YK \\
\hline & $\mathrm{DH}$ & Teminat & & PYB & MDP Ön inceleme Süreci \\
\hline & $\mathrm{DH}$ & Sehir & & PYB & MDP Sözlesme \\
\hline & $\mathrm{DH}$ & Sehirici & & PYB & TD Dönemi \\
\hline & $\mathrm{DH}$ & Ylllık İzin & & PYB & TD Hazırlık \\
\hline & $\mathrm{DH}$ & Yurtdisı & & $\mathrm{IDB}$ & Düzenli İzleme Zivaretleri \\
\hline & İGS & Arastırma ve Yavin & & iDB & Ödemeler \\
\hline & İGS & Bölge Planı & 4 & IDB & Planlama ve İlk İzleme \\
\hline & İGS & BKP Uvgulama & 4 & KİB & Ağırlığının \\
\hline & İGS & Proie Basvuru Süreci & 4 & KİB & Organizasvon \\
\hline & PYB & Basvuru Rehberi ve & 4 & KİB & Tanitim Matervallerinin \\
\hline & PYB & Basvurularin & 4 & YDO & Danısmanlık \\
\hline & PYB & DFD Basvuruların & & YDO & İs Takiv \\
\hline
\end{tabular}

Kamu

Sektöründe

Süreç

Yapılandırma-

sına Teknik

Bir Yaklaşım:

Kalkınma

Ajansları

Üzerinde

COBIT-5 ile

Analiz ve

Modelleme

Kaynak: Araştırmacının kendi çalışmasıdır. 
Kamu

\section{Sektöründe}

Süreç

Yapılandirmasina Teknik

Bir Yaklaşım:

Kalkınma

Ajansları

Üzerinde

COBIT-5 ile

Analiz ve

Modelleme

36
Yukarıda belirtilen süreçlere ait iş akışları elektronik ortamda hazırlanmıştır. İlgili süreç sorumluları süreçle ilgili her hangi bir değişiklik olması durumunda veya kontrol noktaları ile ilgili bir değerlendirme, not veya risk derecelendirmesi yapılması gerekli gördüğü durumlarda bu süreç akışları yenileyemediği gibi süreç sorumluları ve ilgili personel uygulamada bu akışlara çok dikkat etmemektedir.

İş akışları, Paydaş İlişkileri Veri tabanında (PVT) yazı halinde girilen verilerin grafiklere otomatik bir şekilde dönüştürülmesiyle süreç haritaları kolaylıkla elde edilebilmektedir. Ancak burada olması gereken süreçlerle uygulanan süreçler arasında nereye oturduğu tam olarak belirlenememektedir. Zira mevzuata göre işlemesi gereken süreçler haritalara aktarıldığı halde uygulamada personelin veya birimin tercihlerine göre mevcut süreçler farklılık gösterebilmektedir. Bu durumda süreç haritalarına her hangi bir ihtiyaç duyulmadığı sadece olması iyi olur yaklaşımına ve mali yeterlilik denetimi kapsamında istenmesi gerektiğinden dolayı hazırlanmış idealize edilebilecek bir durumsallık göstermektedir.

Tablo 6. Örnek Disiplin Süreci Oluşturulması

\begin{tabular}{|c|c|c|c|c|c|c|c|c|}
\hline$\frac{\Xi}{\tilde{Z}}$ & 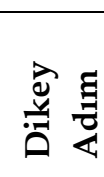 & 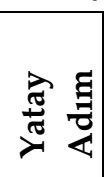 & 吉: & :0ّ & \multicolumn{2}{|l|}{$\frac{\xi}{\&}$} & 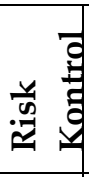 & $\begin{array}{l}\text { 펼 }:=0 \\
\text { : }\end{array}$ \\
\hline 1 & 2 & & $\begin{array}{l}\text { Başlan } \\
\text { gıç }\end{array}$ & $\begin{array}{l}\text { İlgili } \\
\text { Personel }\end{array}$ & Başlangıç & & & \\
\hline 2 & 3 & & İşlem & $\begin{array}{l}\text { İlgili } \\
\text { Birim } \\
\text { Başkanı }\end{array}$ & $\begin{array}{l}\text { Personelin } \\
\text { Yönergesine } \\
\text { davranışlarının } \\
\text { halinde bir } \\
\text { düzenlenerek } \\
\text { Sekretere sunulmas }\end{array}$ & $\begin{array}{r}\text { Disiplin } \\
\text { aykırı } \\
\text { tespiti } \\
\text { rapor } \\
\text { Genel }\end{array}$ & $\tilde{1} 2$ & 1 \\
\hline 3 & 4 & & İşlem & $\begin{array}{l}\text { Genel } \\
\text { Sekreter }\end{array}$ & $\begin{array}{ll}\text { Disiplin } & \text { so } \\
\text { açılacak } \mathrm{ml} ? & \end{array}$ & şturması & 7 & A \\
\hline
\end{tabular}

${ }^{1}$ Burada ilgili personel sürecin işleyişi veya risk değerlendirmesiyle ilgili bir yorum yazarak akışın belirlenmesinden sorumlu olan personele yardımcı olabilmektedir.

${ }^{2}$ Buradaki ünlem işareti riskle ilgili bir değerlendirmenin risk kütüğünde mevcut olduğunu ünlem işareti olmayanlar ise tersine durumu ifade etmektedir. 


\begin{tabular}{|c|c|c|c|c|c|c|c|}
\hline 4 & 5 & & İşlem & İç Denetçi & $\begin{array}{lr}\text { Toplantı } & \text { gündeminin } \\
\text { belirlenmesi, } & \text { disiplin } \\
\text { soruşturmasina } & \text { konu } \\
\text { eylemin } & \text { belirlenmesi, } \\
\text { ilgiliden savunma istenmesi } \\
\text { ve tüm evrakın İ'ya } \\
\text { iletilmesi }\end{array}$ & 4 & A \\
\hline 5 & 6 & & İşlem & $\begin{array}{l}\text { İK } \\
\text { Sorumlus } \\
\mathrm{u}\end{array}$ & $\begin{array}{l}\text { Soruşturma raporunun } \\
\text { hazırlanması ve Disiplin } \\
\text { Kuruluna sunulması }\end{array}$ & 4 & A \\
\hline 6 & 7 & & İşlem & $\begin{array}{l}\text { Disiplin } \\
\text { Kurulu }\end{array}$ & $\begin{array}{l}\text { Konunun görüşülerek karara } \\
\text { bağlanması, cezanın tespit } \\
\text { edilmesi }\end{array}$ & (1) & A \\
\hline 7 & 8 & 9 & $\begin{array}{l}\text { Koşul / } \\
\text { Karar }\end{array}$ & $\begin{array}{l}\text { Genel } \\
\text { Sekreter }\end{array}$ & $\begin{array}{l}\text { Ceza iş akdi feshi içeriyor } \\
\text { mu? }\end{array}$ & 4 & A \\
\hline 8 & 9 & & İşlem & $\begin{array}{l}\text { Yönetim } \\
\text { Kurulu }\end{array}$ & $\begin{array}{lr}\text { Ceza iş akdi } & \text { feshi ise } \\
\text { onaylanmak } & \text { üzere } \\
\text { görüşülmesi } & \end{array}$ & 4 & A \\
\hline 9 & 10 & & İşlem & $\begin{array}{l}\text { İK } \\
\text { Sorumlus } \\
\mathrm{u}\end{array}$ & $\begin{array}{l}\text { Cezanin yazılıp Genel } \\
\text { Sekreter onayına sunulması }\end{array}$ & 4 & A \\
\hline 10 & 11 & 14 & $\begin{array}{l}\text { Koşul / } \\
\text { Karar }\end{array}$ & $\begin{array}{l}\text { İlgili } \\
\text { Personel }\end{array}$ & Karara itiraz etti mi? & 4 & \& \\
\hline 11 & 12 & & İşlem & $\begin{array}{l}\text { Yönetim } \\
\text { Kurulu }\end{array}$ & $\begin{array}{l}\text { Personele ait performans } \\
\text { raporlarının, taltif ve diğer } \\
\text { cezaların, Disiplin Kurulu } \\
\text { Başkanının görüşlerinin } \\
\text { dinlenmesi }\end{array}$ & 4 & A \\
\hline 12 & 13 & & İşlem & $\begin{array}{l}\text { Yönetim } \\
\text { Kurulu }\end{array}$ & Ceza onay/ret? & 4 & A \\
\hline 13 & 14 & & İşlem & $\begin{array}{l}\text { İK } \\
\text { Sorumlus } \\
\mathrm{u}\end{array}$ & $\begin{array}{l}\text { Sonucun personele tebliğ } \\
\text { edilmesi }\end{array}$ & 4 & St \\
\hline
\end{tabular}

Kamu

Sektöründe

Süreç

Yapılandırma-

sina Teknik

Bir Yaklaşım:

Kalkınma

Ajansları

Üzerinde

COBIT-5 ile

Analiz ve

Modelleme 


\section{Kamu}

\section{Sektöründe}

Süreç

Yapılandirma-

sina Teknik

Bir Yaklaşım:

Kalkınma

Ajansları

Üzerinde

COBIT-5 ile

Analiz ve

Modelleme

38

\begin{tabular}{|c|c|c|c|c|c|c|c|c|}
\hline 14 & 15 & İşlem & $\begin{array}{l}\text { Genel } \\
\text { Sekreter }\end{array}$ & $\begin{array}{l}\text { Sonucun } \\
\text { basskanına } \\
\text { bildirilmesi }\end{array}$ & $\begin{array}{l}\text { ilgili } \\
\text { yazilı }\end{array}$ & $\begin{array}{l}\text { birim } \\
\text { olarak }\end{array}$ & 4 & $A$ \\
\hline 15 & & Bitiş & $\begin{array}{l}\text { İlgili } \\
\text { Personel }\end{array}$ & Bitiş & & & & \\
\hline
\end{tabular}

Kaynak: Araştırmacının ANKA belgelerinden esinlenerek yaptığı çalışmadır.

Tablodan da görüleceği üzere, temel süreçler üzerinden hazırlanan iş süreçleri bilgilendirme amacıyla hazırlanmış olup olması gereken (to-be) süreçleri yansıtmaktadır. Bu süreçlerde mevcut uygulamaların nasıl yapıldığına ve istisnai olarak ne tür atlama ve farklı uygulama biçimlerinin olduğuna dair bilgi yer almamaktadır. Ancak her bir süreç üzerindeki kontrol noktalarının mevcut olması ne tür kontrollerin yapılması gerektiği hakkında fikir vermektedir. Ayrıca uygulayıcıların süreçlerdeki kontroller ile ilgili yorum yapabilecekleri bir fonksiyonun olması da bu anlamda iç kontrol ortamının gelişmesine katkıda bulunabilecek bir özellik olarak anlaşılmaktadır.

Sonuç olarak, araştırma sorularımız aşağıdaki şekilde cevaplanabilmektedir:

DDK tarafindan tespit edilen sorunlardan KA süreçlerinin doğru yapılandırılmaması ile ilişkili olan sorun var mıdır? Varsa hangileridir ve nasıl ilişkilendirilebilmektedir?

Devlet Denetleme Kurulu (DDK) tarafından 2014 yılında kalkınma ajanslarının (KA) 43 adet önemli sorunları olduğu yönünde hazırlanan araştırma raporundaki tespitlere dayanmaktadır. KA süreçlerinin doğru 
yapılandırılmamış olmasıyla doğrudan ilişkisi olabilecek sorunlardan "bağımsız değerlendiricilerin seçim ve değerlendirme usulleri yetersizliği" ile " bütçe revizyonlarında ölçüsüzlük" ele alınmıştır. Buna göre çoğu sorunun aslında KA süreçlerinin işletilmesiyle doğrudan veya dolaylı bir şekilde ilişkili olduğu tespit edilmiştir. Örnek olarak sadece iki adet sorun ile ilgili kök neden analizleri aşağıda yapılmaktadır. Bu analizde karşılaştırmalı olarak COSO ve COBIT modelleri kullanılmıştır. Bağımsız değerlendiricilerin seçim ve değerlendirme usulleri mevzuatça belirlenmekte ve diğer detaylar ise mali destek programı rehberinde YK tarafından belirlenmektedir. Mevzuattaki sınırlamalar kaldırılarak kamu personelinden de yararlanabilmenin daha kolay hale getirilmesi paydaş ihtiyaçları ve bütüncül yaklaşım kapsamında değerlendirilmelidir. Bağımsız değerlendiricilerin seçim ve değerlendirme usullerinin yetersiz olması bu konuda sürecin paydaş ihtiyaçları ve kurumsal hedefler doğrultusunda sistematize edilmemiş olduğunu göstermektedir. Bütçe revizyonları ile ilgili yapılandırılmış bir sürecin olmaması da yönetim süreçlerinin sorunlu olduğunu göstermektedir. Bütçe revizyonunun her bir proje için yapılıyor olması ciddi bir kaynak israfı olduğu gibi bütçe kalemleri üzerinde değerlendirme yapılarak proje geçer not aldığından dolayı değerlendirme kriterlerinin sonradan değişmesi anlamına gelebilir. Ayrıca bu anlamda bir ihtiyaç varsa paydaşların bu ihtiyaçları potansiyel başvuru sahiplerine başvuru öncesi danışmanlık ve rehberlik yapılarak hazırlayacakları bütçelerin tutarlı ve piyasa koşullarına uygun olması önceden sağlanabilir. Bunun için de paydaş ihtiyaçları ve kurumsal hedefler doğrultusunda süreçlerin yeniden yapılandırılması gerekir.

COBIT-5 süreç gerçekleştiricisi nedir ve KA dinamiklerinde nasıl uygulanabilir?

COBIT-5 çerçeve olarak uygulanabilirliğini 5 ilke ile 7 gerçekleştiriciye bağladığından bir gerçekleştirici olarak süreçler de bu kapsamda ele alınmaktadır. Süreç modelinin gerçekleştirici boyutu da ilkeler, politikalar ve çerçeveler gerçekleştiricisinde olduğu gibi; paydaşlar, hedefler, yaşam döngüsü ve iyi uygulamaları içermektedir.

COBIT-5 sistematiğinin KA dinamiklerinde uygulanabilmesi için yaşam döngüsü yaklaşımı (ISACA., 2012a) benimsenmiştir. Yaşam döngüsünün uygulanması, uygulama sırasında karşılaşılan karmaşıklıklara ve tipik zorluklara COBIT-5 kullanarak hitap etme olanağ 1 sağlar. Yaşam döngüsünün birbiriyle ilişkili üç bileşeni şunlardır:

a) Tek seferlik bir proje olmadığından yaşam döngüsünün sürekli geliştirilmesi 
Kamu

Sektöründe

Süreç

Yapilandirmasina Teknik

Bir Yaklaşım:

Kalkınma

Ajansları

Üzerinde

COBIT-5 ile

Analiz ve

Modelleme

40 b) Davranışsal ve kültürel boyutlara değişime olanak tanıma

c) Programın yaşam döngüsü çerçevesinde yönetimi

Uygulamanın başarısı ya da girişimin gelişmesini garanti altına almak için uygun ortam oluşturulmalıdır. (ISACA., 2012a) Bu çalışmanın tamamen uygulanması noktasında uygun ortamın (mevzuat değişikliği, yönetim iradesi, uygulayıcıların eğitimi) henüz mevcut olmadığı tespit edilmiş ve bu aşağıdaki şekilde yaşam döngüsü ve yedi aşaması gösterilebilmiş ve KA dinamiklerine göre modellenebilmiştir. Ancak, modelin orijinalinde mevcut olan 6. aşamadaki "karı gerçekleştirme"nin kamu sektörü kapsamında olan KA için "bölgesel kalkınmayı sağla" şeklinde uygulanması önerilmiştir.

\section{Kaynakça}

Cronemyra, P., \& Danielsson, M. (2013). Process Management 1-2-3 - a maturity model and diagnostics tool. Total Quality Management, 933-944.

DDK, Aykın, H., ARSLANBAŞ, M., DERE, A., ÖZÇELIK, A., BOYALI, C., . . ÖZKILINÇ, M. A. (2014). Kalkınma Ajansları Inceleme ve Araştırma Raporu (Hizmete Özel). Ankara: Cumhurbaşkanlığı Devlet Denetleme Kurulu, http://www.tccb.gov.tr/faaliyetler/ddkraporlari/.

Efe, A. (2015). Türkiye'de Kalkınma Ajansları için Bir Yönetişim Modellemesi: COBIT-5. Ankara: TODAIE (Basılmamış Doktora Tezi).

ISACA. (2012). COBIT 5: A Business Framework for the Governance and Management of Enterprise IT. Rolling Meadows, IL: ISACA.

ISACA. (2012a). COBIT 5 Implementation. . Rolling Meadows, IL: ISACA.

KB-BGYUGM. (2014). DEVLET DENETLEME KURULU KALKINMA AJANSLARI ARAŞTIRMA VE INCELEME RAPORU KAPSAMINDA ALINACAK TEDBIRLER. Ankara: Kalkınma Bakanlığı (hizmete özel).

Mař́iková, M., Rolínek, L., Kubecová, J., \& Vrchota, J. (2015). Relationship Between The Extent Of Implementation Of The Process Management Principles and the Legal Form of the Business and Business Activity. Serbian Journal of Management, $109-116$.

Stefan Schulte, C. J., Venugopal, S., Weber, I., \& Hoenisch, P. (2015). Elastic Business Process Management: State of the art and open challenges for BPM in the cloud. Future Generation Computer Systems, 36-50.

Suriadi, S., Weiß, B., Winkelmann, A., Hofstede, A. H., Adams, M., Conforti, R., . . . Wynn, M. (2014). Current Research in Risk-aware Business Process Management-Overview, Comparison, and Gap Analysis. Communications of the Association for Information Systems, 933-984. 
İsletme Bilimi Dergisi (JOBS), 2016; 4(2): 1-52. DOİ: 10.22139/jobs.287244

Kamu

Sektöründe

Süreç

Yapılandırma-

sına Teknik

Bir Yaklaşım:

Kalkınma

Ajansları

Üzerinde

COBIT-5 ile

Analiz ve

Modelleme

41 